\title{
The WAMME regional model intercomparison study
}

\author{
Leonard M. Druyan • Jinming Feng $\cdot$ Kerry H. Cook $\cdot$ Yongkang Xue $\cdot$ \\ Matthew Fulakeza $\cdot$ Samson M. Hagos • Abdourahamane Konaré • \\ Wilfran Moufouma-Okia • David P. Rowell $\cdot$ Edward K. Vizy $\cdot$ Seidou Sanda Ibrah
}

Received: 25 May 2009/Accepted: 25 September 2009/Published online: 15 October 2009

(C) The Author(s) 2009. This article is published with open access at Springerlink.com

\begin{abstract}
Results from five regional climate models (RCMs) participating in the West African Monsoon Modeling and Evaluation (WAMME) initiative are analyzed. The RCMs were driven by boundary conditions from National Center for Environmental Prediction reanalysis II data sets and observed sea-surface temperatures (SST) over four May-October seasons, (2000 and 2003-2005). In addition, the simulations were repeated with two of the RCMs, except that lateral boundary conditions were derived from a continuous global climate model (GCM) simulation forced with observed SST data. RCM and GCM simulations of precipitation, surface air temperature and
\end{abstract}

This paper is a contribution to the special issue on West African Climate, consisting of papers from the African Multidisciplinary Monsoon Analysis (AMMA) and West African Monsoon Modeling and Evaluation (WAMME) projects, and coordinated by Y. Xue and P. M. Ruti.

L. M. Druyan $(\varangle) \cdot$ M. Fulakeza

CCSR, Columbia University and NASA/Goddard Institute

for Space Studies, New York, USA

e-mail: LDruyan@giss.nasa.gov

\section{J. Feng}

Institute of Atmospheric Physics,

Chinese Academy of Sciences, Beijing, China

J. Feng · Y. Xue

Department of Atmospheric and Oceanic Sciences,

University of California at Los Angeles, Los Angeles,

CA, USA

K. H. Cook

Jackson School of Geosciences,

The University of Texas at Austin, Austin, TX, USA

S. M. Hagos

Rosenstiel School of Marine and Atmospheric Sciences,

University of Miami, Miami, FL, USA circulation are compared to each other and to observational evidence. Results demonstrate a range of RCM skill in representing the mean summer climate and the timing of monsoon onset. Four of the five models generate positive precipitation biases and all simulate negative surface air temperature biases over broad areas. RCM spatial patterns of June-September mean precipitation over the Sahel achieve spatial correlations with observational analyses of about 0.90 , but within two areas south of $10^{\circ} \mathrm{N}$ the correlations average only about 0.44 . The mean spatial correlation coefficient between RCM and observed surface air temperature over West Africa is 0.88 . RCMs show a range of skill in simulating seasonal mean zonal wind and meridional moisture advection and two RCMs overestimate moisture convergence over West Africa. The $0.5^{\circ}$ computing grid enables three RCMs to detect local minima related to high topography in seasonal mean meridional

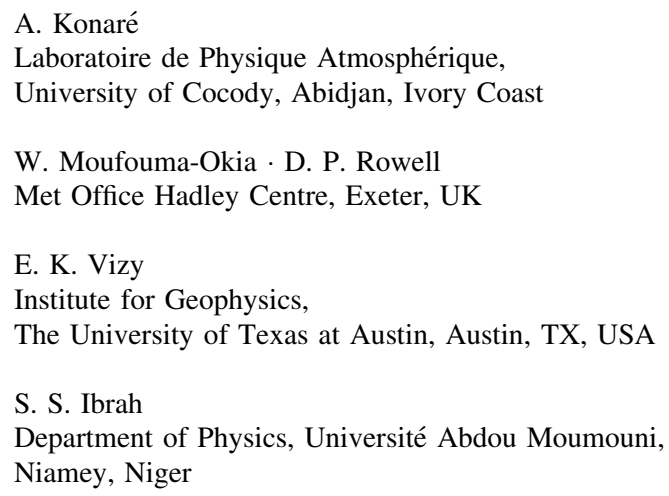


moisture advection. Sensitivity to lateral boundary conditions differs between the two RCMs for which this was assessed. The benefits of dynamic downscaling the GCM seasonal climate prediction are analyzed and discussed.

Keywords West African monsoon .

Regional climate models · Dynamic downscaling

\section{Introduction}

The West African Monsoon Modeling and Evaluation (WAMME) is an international project that investigates WAM/external forcing feedbacks by analyzing simulations of state-of-the-art general circulation models (GCMs) and regional climate models (RCMs). Xue et al. (2009) discuss the WAMME initiative, its approaches to improve WAM simulations, the first phase of WAMME experiments and some preliminary results. This paper provides a more focused evaluation of the WAMME RCM simulations. One objective of WAMME is to evaluate the potential for downscaling seasonal climate forecasts over West Africa. The limited area domains of RCMs allows them to be integrated at high horizontal resolutions that can account for detailed features of terrain and land surface characteristics (Denis et al. 2002; De Ela et al. 2002; Druyan et al. 2007), and to resolve the exceptionally strong and dynamically important meridional temperature and moisture gradients that characterize the West African climate in summer (Cook 1999, Paeth et al. 2005). At the same time, the increased spatial detail of climate fields simulated with RCMs provides added information on space scales of interest for the users of seasonal predictions. This study evaluates the extent to which this greater spatial detail of RCM fields provides useful climate information.

The quality of climate model simulations depends in large measure on the performance of the models' parameterizations of physical processes. In addition, RCMs are sensitive to the synchronous forcing data used as lateral boundary conditions (LBC). For example, in an application over South America, Rojas and Seth (2003) find that GCM forcing produce excessive Nordeste rainfall in their RCM simulations compared with reanalysis data forcing. They trace the degradation to the poor location of the Atlantic intertropical convergence zone (ITCZ) in the GCM simulation. Messager et al. (2004) report on simulation experiments with the MAR regional atmospheric model at $40 \mathrm{~km}$ grid spacing over West Africa, forced by ERA15 reanalysis and SST data for January-October 1983 and 1984. The simulations realistically model the northward monsoon jump (onset) and demonstrate the influence of sea-surface temperatures on the 1984 minus 1983 precipitation differences over the Sahel. An evaluation of regional climate models' potential for making seasonal forecasts must examine both the skill of the models' configurations as well as the influence of the LBCs. Sylla et al. (2009) force a regional climate model over West Africa with LBCs alternatively from reanalysis and from an atmospheric-ocean GCM. This paper compares the performance of the RCMs with respect to their timing of monsoon precipitation onset, precipitation bias, spatial precipitation and temperature patterns, moisture advection within the monsoon layer, moisture convergence and vertical crosssections of zonal wind. The study considers RCMs forced by LBCs from the National Center for Environmental Prediction (NCEP) reanalysis II in order to evaluate general model performance. These results are subsequently compared with simulations for two of the models forced by GCM LBCs.

\section{Models, data and experiments}

Results from five RCMs are described below. All are integrated using a horizontal grid with approximately $0.5^{\circ}$ spacing over the domain $20^{\circ} \mathrm{S}-35^{\circ} \mathrm{N}$ and $35^{\circ} \mathrm{W}-35^{\circ} \mathrm{E}$. Figure 1 shows the domain, the topography on the $0.5^{\circ}$ grid and four sub-regions referred to below for verification statistics. The RM3 of the NASA/Goddard Institute for Space Studies and Columbia University has 28 vertical sigma levels and is described by Druyan et al. (2008). The UK Met Office Hadley Centre RCM is known as HadRM3P (Jones et al. 2004). It was developed from HadAM3 (Pope et al. 2000) with further improvements to the physics, with the aim of providing more detailed and more reliable climate change scenarios. It is run on a $0.44^{\circ} \times 0.44^{\circ}$ horizontal grid with 19 vertical sigma levels. The MM5 RCM (Grell et al. 1994) was developed at the

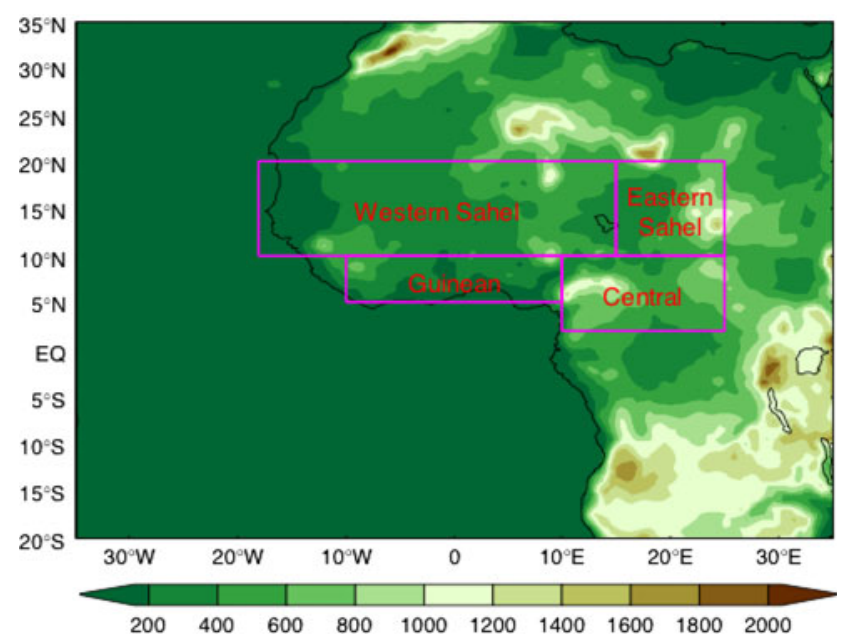

Fig. 1 Domain for each RCM simulation, land topography (m) and four sub-regions for verification statistics 
National Center for Atmospheric Research, modified for West African simulation and run at Cornell University with 24 vertical levels (see Vizy and Cook 2002). The RegCM3 (Afiesimama et al., 2006; Pal et al. 2007) was run at the Université Abdou Moumouni (UAM, Niamey, Niger) with 18 vertical levels. Additional perspective was gained by examining results from the RegCM3 run at the University of Cocody (UC, Ivory Coast), with different SST forcing, as explained below. The various moist convection and ground hydrology schemes of the models are identified by Druyan et al. (2008), Jones et al. (2004), Grell et al. (1994) and Pal et al. (2007).

As mentioned above, LBCs for the first round of simulations were taken from the NCEP reanalysis II (Kanamitsu et al. 2002), except that observed sea-surface temperatures (SSTs) were specified, from HadlSST1 (Rayner et al. 2003) for four models and from the Optimum Interpolated SST (OISST, Reynolds et al. 2002) for the UC RegCM3. Monthly mean SSTs were, in each case, interpolated to daily values using the variance correction method of Taylor et al. (2000). Four seven-month simulations were begun from NCEP reanalysis II initial conditions on April 1, 2000, 2003, 2004 and 2005. The SST forcing corresponds to April 1-October 31 of each year. The HadRM3P RCM uses initial soil moisture and soil temperature fields at four vertical levels spun up from a multi-year integration driven by the reanalysis (Moufouma-Okia and Rowell 2009). RM3 and MM5 initialize soil moisture and temperature at three vertical levels from reanalysis data on April 1 of each year, while both RegCM3 models initialize with climatological values consistent with soil type at each of three soil levels. Since surface temperatures are sensitive to surface evaporation, and since local evaporation is one source of moisture for precipitation, one might expect the evolving climate to be sensitive to the specification of initial soil moisture. This issue is not considered in the present study, but experiments with HadRM3P reported elsewhere (Moufouma-Okia and Rowell 2009) did not detect any significant sensitivity to the specification of initial soil moisture.

GCM LBCs for the second set of experiments considered by this paper were generated by the Hadley Centre HadAM3 model (Pope et al. 2000), run at $2.5^{\circ} \times 3.75^{\circ}$ with 19 vertical levels. In order to separate the influence of SST from atmospheric forcing, the GCM simulation and the experiments downscaling it also used observed SSTs from HadlSST1 (as if they were "perfect" SST forecasts), as in the first set of experiments. The interannual variability of the West African summer monsoon climate is considerably influenced by SST anomalies (Folland et al. 1986; Rowell 2001, 2003; Giannini et al. 2003). Accordingly, GCM simulations forced by realistic SSTs should contain a climate forcing signal for West Africa. The GCM LBC data were provided from one continuous simulation forced with HadlSST1 boundary conditions from 1949 through 2007. For each RCM, four seven-month simulations, begun from GCM initial atmospheric and soil moisture conditions on April 1, used HadlSST1 lower boundary conditions as described above for the first stage experiments. Results of downscaling the GCM simulation are described below for the RM3 and the HadRM3P since second stage experiments were not run with MM5 and RegCM3.

\section{Results}

\subsection{Seasonal march of precipitation}

Figure $2 \mathrm{a}$ and $\mathrm{b}$ show the seasonal progression (time vs. latitude) of observed 5-day mean precipitation averaged between $10^{\circ} \mathrm{W}-10^{\circ} \mathrm{E}$ for June-September, averaged over 2000, 2003, 2004 and 2005. Figure 2a uses operational rain gauge data (Global Telecommunications System) from NOAA's Climate Prediction Center (CPC) on a $0.5^{\circ}$ grid (Xie et al., 2007), while Fig. 2 b shows CPC Merged Analysis of Precipitation (CMAP) data. CMAP pentad means are a blend of observations from rain gauges and precipitation estimates from several infrared and microwave satellite-based algorithms (Huffman et al., 1997), but they represent the precipitation distribution on a rather coarse $2.5^{\circ}$ grid.

The West African monsoon (WAM) is characterized by the advance of precipitation northward to the Sahel region during late June or early July and its southward retreat during September. Precipitation over the Gulf of Guinea coast (about $6^{\circ} \mathrm{N}$ ) typically wanes near the end of June and thereafter reforms over the Sahel closer to $10^{\circ} \mathrm{N}$. The initial establishment of the rainfall maximum near $10^{\circ} \mathrm{N}$ is a northward "jump" (Hagos and Cook, 2007; Sultan and Janicot, 2000; Ramel et al., 2006) that is related to increased continental sensible heating which, in turn, initiates a surge in moisture convergence over the Sahel. The discontinuity is related to the development of inertial instability over the Guinean coast region (Hagos and Cook 2007), and a model must resolve the meridional zonal wind gradients properly to simulate the instability. The ability of RCMs to reproduce the northward migration of the rain belt and its subsequent retreat is fundamentally important to both their usefulness in forecasting and climate sensitivity studies. Skillful simulation of the northward jump is especially desirable since it represents the onset of monsoon rains over the semi-arid Sahel region. Although different dates of the northward jump during each of the 4 years represented in Fig. 2 would detract from a sharp demarcation, the observed 4 year mean clearly shows a rainfall maximum along $5^{\circ} \mathrm{N}$ until early July when heavier 

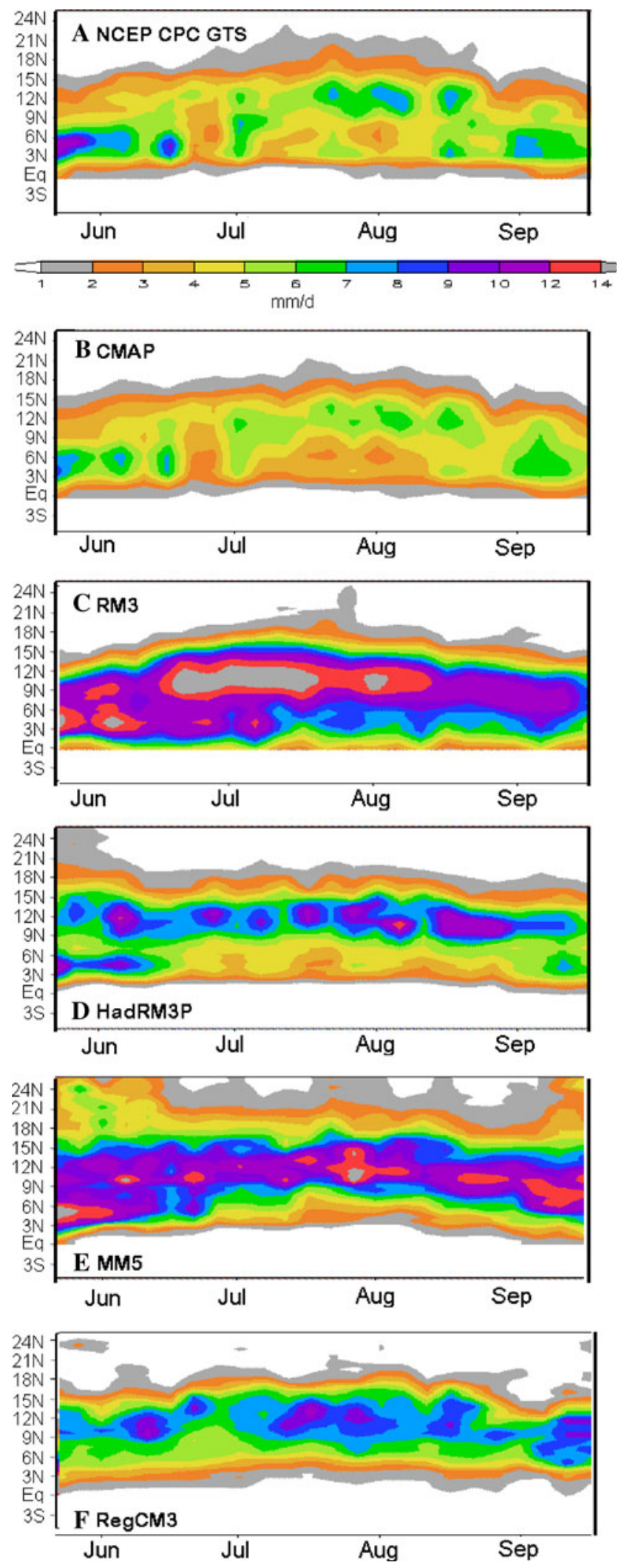

Fig. 2 Seasonal progression (time vs. latitude) of 5-day mean precipitation averaged between $10^{\circ} \mathrm{W}$ and $10^{\circ} \mathrm{E}$ rates begin to appear near $12^{\circ} \mathrm{N}$. CPC and CMAP data both show an interruption of heavy precipitation followed by resumption within a broad band $3^{\circ} \mathrm{N}-12^{\circ} \mathrm{N}$. For most of July, August and early September, both observational sets show a concentration of precipitation centered near $12^{\circ} \mathrm{N}$.

The following discussion refers to four regional model simulations of these four seasons forced by NCEP reanalysis II. Results are not shown for the UAM RegCM3 for which daily fields are not available. All four RCMs overestimate rainfall compared to observations. The RM3 (Fig. 2c) produces the largest exaggerations of peak rainfall and the HadRM3P (Fig. 2d) and RegCM3 (Fig. 2f) the lowest. The RM3 also sustains exaggerated precipitation rates along the Gulf of Guinea coast $\left(6^{\circ} \mathrm{N}\right)$ throughout the summer. MM5 (Fig. 2e) expands the rain band too far north into the Sahara. HadRM3P favors a double ITCZ during June, creating the maximum near $12^{\circ} \mathrm{N}$ much too early, while simultaneously maintaining a fairly realistic rain band along $5^{\circ} \mathrm{N}$. This early onset of Sahel precipitation, accompanied by light rain as far north as $24^{\circ} \mathrm{N}$, in HadRM3P and MM5, runs contrary to observational evidence.

Each RCM simulation produces a version of the West African monsoon jump, but with some distortion of structure and/or timing. (The jump is also captured in the RCM study of Hagos and Cook (2007) using the same MM5 RCM, but with the experimental design specifically optimized for West Africa compared to the WAMME protocol utilized here). Variations between the models could relate to their different rates of ground heating, which in turn relates to soil moisture and cloudiness, but this hypothesis has not been tested. Both the RM3 (Fig. 2c) and the MM5 (Fig. 2e) capture fairly clean jumps, with rainfall along the coast diminishing before the onset in the Sahel, but both are earlier than in the observations (Figs. 2a, b). RegCM3 (Fig. 2f) simulates a northward jump during the first week in June (not shown), almost a month too early, with another discontinuity in the second half of June that brings high rainfall rates into the Sahel very briefly.

The observations show an equatorward transition of the rainfall maximum in early September, which RM3, MM5, and RegCM3 do capture. The transition in HadRM3P is discontinuous, yielding a double (overlapping) ITCZ not supported by observations. The seasonal migration of the northern boundary of the rain band describes a gentle arc on the time-latitude plot. The sharp gradient of precipitation rates between the Sahel and the Sahara desert advances northward until August when it reverses direction and retreats for the remainder of the summer. The RM3 handles the seasonal march of this gradient realistically. 


\subsection{Mean June-September precipitation distributions}

Figure $3 \mathrm{~b}-\mathrm{f}$ show the spatial distribution of June-September 2000, 2003-2005 RCM precipitation biases relative to CPC observations (Fig. 3a). Four of the five models (HadRM3P, RM3 and both RegCM3) underestimate the orographic rainfall along the southwest Atlantic coast by at least $5 \mathrm{~mm} \mathrm{day}{ }^{-1}$, while MM5 exaggerates the rainfall over part of this coastal region by up to $8 \mathrm{~mm} \mathrm{day}^{-1}$. Only the RM3 overestimates the orographic precipitation over the windward slopes of the Cameroon Highlands, while the other four RCMs produce underestimates. All except the UAM RegCM3 produce positive precipitation biases in a zonal swath across West Africa. The RM3 and MM5 positive biases extend southward to the Gulf of Guinea coast and the MM5 bias also extends northward into the Sahara. The positive precipitation bias of the UC RegCM3 (Fig. 3e) may be related to its OISST forcing, since the UAM RegCM3 with HadlSST1 forcing produces near zero bias over most of West Africa (Fig. 3f). Additional testing of this hypothesis is left for future study.

Table 1 summarizes the quantitative comparison between modeled June-September 2000, 2003, 2004 and 2005 mean precipitation and the corresponding CPC data over four regions (Fig. 1), each with a somewhat different climatic regime. The two areas between $10^{\circ} \mathrm{N}-20^{\circ} \mathrm{N}$ monitor post-onset precipitation, while those south of $10^{\circ} \mathrm{N}$ monitor transition regimes. All data are compared on the models' $0.5^{\circ}$ grid. Included are the root mean square error (rmse) between each model and the observational data set for all grid elements within each area, the spatial correlation coefficients and the biases of the means in each case.

Each score refers to a different aspect of model performance. The rmse indicates the magnitude of the population of errors. For a normal distribution, two-thirds of the errors fall within $\pm 1 \times$ rmse. The spatial correlation coefficients measure the congruence of simulated spatial distributions of precipitation with corresponding CPC
Fig. 3 a June-September 2000 2003-2005 mean precipitation for NCEP CPC GTS. b-f: JJAS 2000, 2003-2005 precipitation biases as differences, model minus NCEP CPC GTS
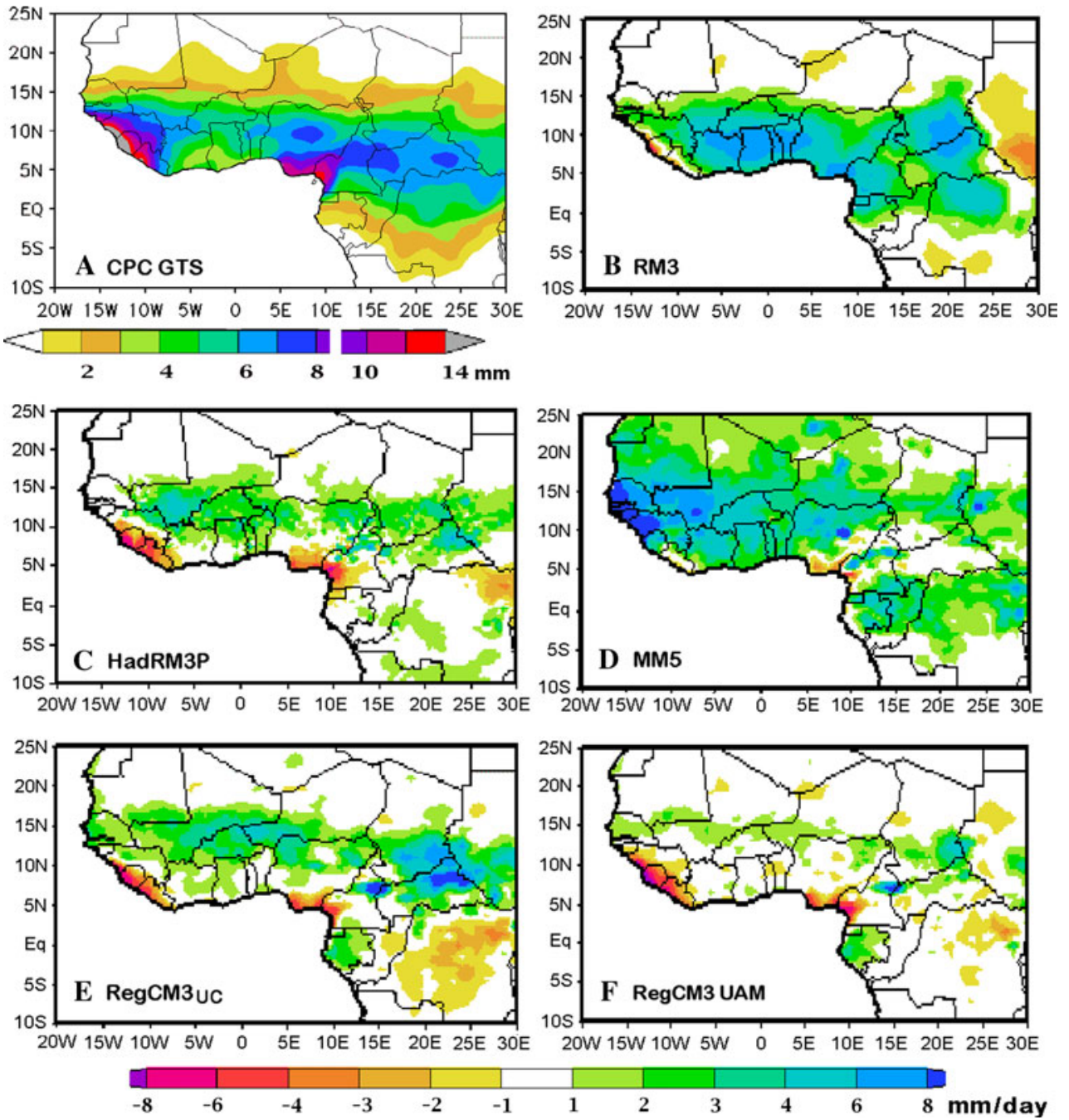
Table 1 Statistical comparison of June-September 2000, 2003-2005 mean precipitation rates for each regional model against CPC GTS observations, gridded at $0.5^{\circ}$ within four regions

\begin{tabular}{|c|c|c|c|}
\hline Model & $\begin{array}{l}\text { rmse } \\
\left(\mathrm{mm} \mathrm{day}^{-1}\right)\end{array}$ & $\begin{array}{l}\text { Correlation } \\
\text { coefficient }\end{array}$ & $\begin{array}{l}\text { Bias } \\
\left(\mathrm{mm} \mathrm{day}^{-1}\right)\end{array}$ \\
\hline \multicolumn{4}{|l|}{ Guinean region } \\
\hline RM3 & 5.32 & 0.56 & 4.99 \\
\hline HADRM3P & 1.95 & 0.36 & -0.01 \\
\hline MM5 & 3.44 & 0.39 & 2.66 \\
\hline RegCM3 UC & 1.55 & 0.56 & 0.12 \\
\hline RegCM3 UAM & 1.56 & 0.66 & -0.8 \\
\hline \multicolumn{4}{|l|}{ Western Sahel } \\
\hline RM3 & 2.32 & 0.94 & 1.31 \\
\hline HADRM3P & 1.77 & 0.91 & 1.21 \\
\hline MM5 & 4.80 & 0.89 & 4.06 \\
\hline RegCM3 UC & 2.00 & 0.90 & 1.51 \\
\hline RegCM3 UAM & 1.03 & 0.91 & 0.35 \\
\hline \multicolumn{4}{|l|}{ Eastern Sahel } \\
\hline RM3 & 2.91 & 0.90 & 1.68 \\
\hline HADRM3P & 1.61 & 0.97 & 1.13 \\
\hline MM5 & 2.32 & 0.87 & 1.84 \\
\hline RegCM3 UC & 2.85 & 0.94 & 1.78 \\
\hline RegCM3 UAM & 1.52 & 0.92 & 0.62 \\
\hline \multicolumn{4}{|l|}{ Central region } \\
\hline RM3 & 3.98 & 0.43 & 3.67 \\
\hline HADRM3P & 2.11 & 0.40 & 0.68 \\
\hline MM5 & 2.00 & 0.32 & 1.17 \\
\hline RegCM3 UC & 3.57 & 0.27 & 1.89 \\
\hline RegCM3 UAM & 1.70 & 0.42 & 0.07 \\
\hline
\end{tabular}

Statistics are root mean square error (rmse), correlation coefficient and bias (difference between the means). Western Sahel: $10^{\circ} \mathrm{N}-20^{\circ} \mathrm{N}$, $18^{\circ} \mathrm{W}-15^{\circ} \mathrm{E}$; Eastern Sahel: $10^{\circ} \mathrm{N}-20^{\circ} \mathrm{N}, 15^{\circ} \mathrm{E}-25^{\circ} \mathrm{E}$; Guinean Region: $5^{\circ} \mathrm{N}-10^{\circ} \mathrm{N}, 10^{\circ} \mathrm{W}-10^{\circ} \mathrm{E}$; Central: $2^{\circ} \mathrm{N}-10^{\circ} \mathrm{N}, 10^{\circ}-25^{\circ} \mathrm{E}$

precipitation distributions. High correlations result when the location and orientation of simulated gradients and extremes match the observed, regardless of whether the magnitudes match. The bias informs about whether the model averages are higher or lower than the validation data.

The scores for the western Sahel $\left(10^{\circ} \mathrm{N}-20^{\circ} \mathrm{N}, 18^{\circ} \mathrm{W}-\right.$ $\left.15^{\circ} \mathrm{E}\right)$ are rather encouraging for all five models, although all generate positive biases in the mean precipitation rate. Only the MM5 mean bias exceeds $1.5 \mathrm{~mm} \mathrm{day}^{-1}$. In addition, all five spatial correlation coefficients are near 0.90 , indicating that the models capture the orientation of the observed precipitation gradients despite their excessive rates. The RegCM3 of UAM achieves a low bias and low rmse as well.

Spatial correlation coefficients are also quite high over the eastern Sahel $\left(10^{\circ} \mathrm{N}-20^{\circ} \mathrm{N}, 15^{\circ} \mathrm{E}-25^{\circ} \mathrm{E}\right)$ and all of the biases for this region are between 0.5 and $2.0 \mathrm{~mm}^{\text {day }}{ }^{-1}$.
The UAM RegCM3 again achieves the lowest rmse and bias, while HadRM3P scores a near perfect spatial correlation against observations.

The scores over the Guinean region $\left(5^{\circ} \mathrm{N}-10^{\circ} \mathrm{N}, 10^{\circ} \mathrm{W}-\right.$ $\left.10^{\circ} \mathrm{E}\right)$ are intermediary from among the four regions. The rmse ranges from 1.55 to $5.32 \mathrm{~mm} \mathrm{day}^{-1}$, the spatial correlation coefficients vary between 0.36 and 0.66 , and the biases between -0.01 and $4.99 \mathrm{~mm} \mathrm{day}^{-1}$. In the best cases, the RegCM3 (UAM) simulated precipitation pattern accounts for only $44 \%$ of the spatial variance in the observed data. RM3 and MM5 precipitation means show rather high positive biases compared to observations.

The precipitation pattern over the central region $\left(2^{\circ} \mathrm{N}-\right.$ $10^{\circ} \mathrm{N}, 10^{\circ} \mathrm{E}-25^{\circ} \mathrm{E}$ ) is the most challenging to simulate. This region includes an orographic maximum above the Cameroon Highlands. Spatial correlations with observations are among the lowest of all the regions for all four models, ranging from 0.27 to 0.43 . All model simulations show a positive bias, although it is near zero for the UAM RegCM3 and small for HadRM3P.

In summary, substantial differences between the models' performance within each domain are evident. Those aspects of RCM performance represented by the spatial correlations with observations are better north of $10^{\circ} \mathrm{N}$. Note that south of $10^{\circ} \mathrm{N}$ the monsoon rain band passes twice during June-September and the topography and land surface characteristics there are also more complex. This gives rise to strong spatial heterogeneity of precipitation, in contrast to the strong zonal pattern of precipitation over the Sahel.

\subsection{Moisture transport and convergence}

Some insight into model performance can be gained by examining moisture advection in the lower troposphere. Although this moisture advection is important in regulating precipitation rates, mid-tropospheric moisture divergence is an additional influence (Rowell et al. 1992; Cook 1999). Figure 4 shows the NCEP reanalysis II and the RCMs' mean $950 \mathrm{mb}$ circulation for June-September 2000, 2003, 2004 and 2005, superimposed on meridional moisture advection. White areas in Fig. $4 \mathrm{~d}$ and $\mathrm{f}$ denote high topography for which no extrapolation was made to $950 \mathrm{mb}$. There is no objective way to determine whether RCM downscaling has produced a more realistic representation of lower tropospheric moisture advection since the NCEP reanalysis II product is also model dependent. However, HadRM3P and both RegCM3 models show a local reduction in the meridional moisture advection in the lee of the Guinean Highlands, which is likely a real feature that reflects their higher resolution of topography compared with NCEP reanalysis II. RM3 reproduces circulation and advection patterns similar to those analyzed in the NCEP 

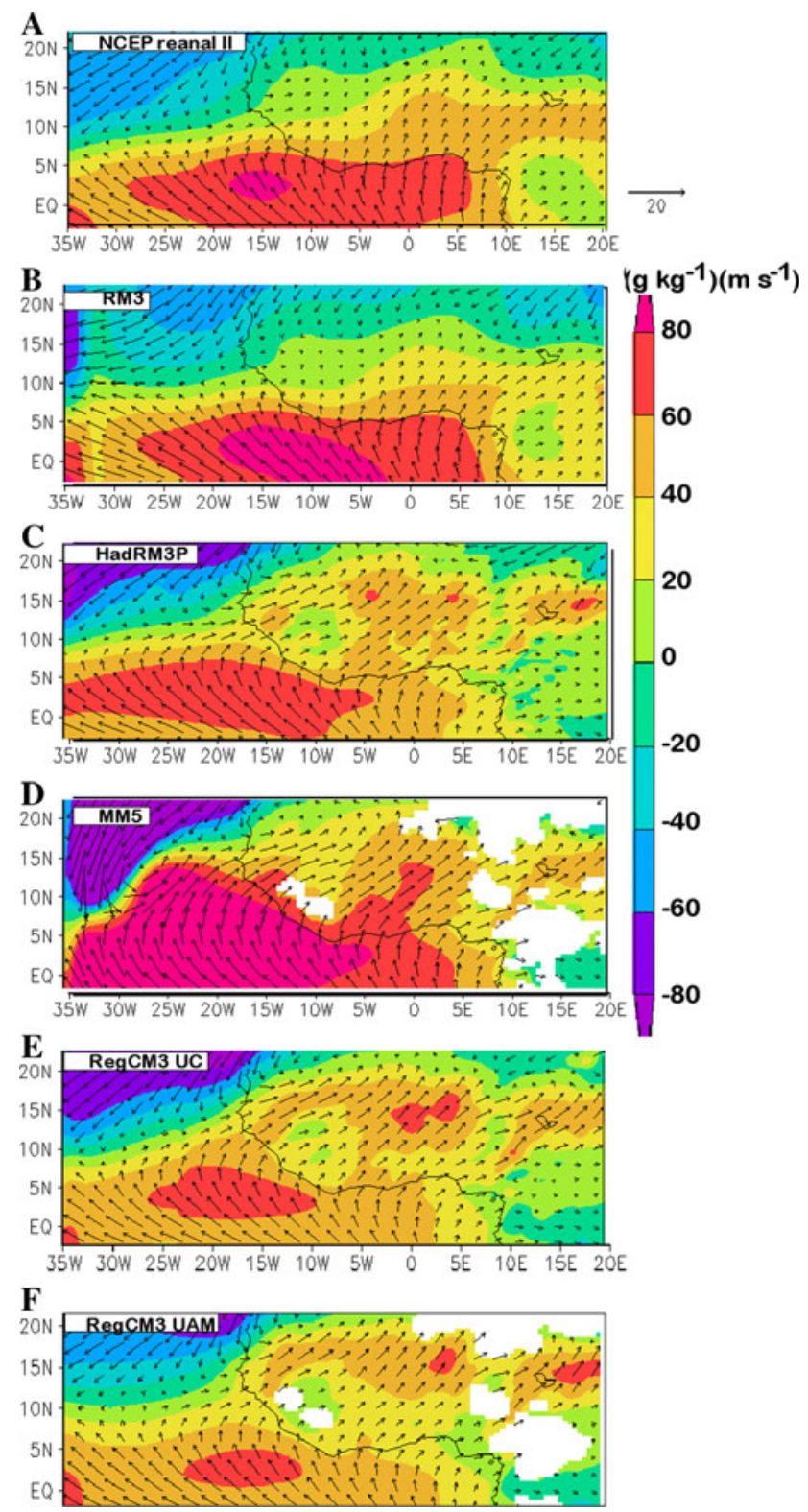

Fig. 4 JJAS 2000, 2003-2005 $950 \mathrm{mb}$ circulation (arrows) and meridional moisture advection $\left(\mathrm{g} \mathrm{kg}^{-1}\right)\left(\mathrm{m} \mathrm{s}^{-1}\right)$. a NCEP reanalysis II, b RM3, c HadRM3P, d MM5, e RegCM3 (UC), f RegCM3 (UAM). Models driven by NCEP reanalysis II LBC (white areas denote high topography for which extrapolation to $950 \mathrm{mb}$ was not made)

reanalysis II data. In particular, the convergence position, demarked by zero meridional moisture advection, is fairly congruent in the two uppermost panels. Note that the positive bias in RM3 precipitation discussed above occurs despite realistic low-level moisture advection, so either excess moisture is converging at other levels, or the modeled moist convection is hyperactive. The other four models bring the northward moisture advection to $20^{\circ} \mathrm{N}$ and beyond over West Africa, which is certainly too far north for a seasonal mean position. In the case of MM5, this deficiency is consistent with the positive bias of simulated rainfall over the Sahara. The very high MM5 northward moisture transports within the Guinean region and along the southwest coast are also consistent with MM5 positive precipitation bias, and are associated with enhanced low-level cyclonic flow over the eastern North Atlantic centered near $13^{\circ} \mathrm{N}$ and $28^{\circ} \mathrm{W}$. This occurs due to the presence of the western boundary at $35^{\circ} \mathrm{W}$, where nudging generates an edge effect that degrades the simulation over West Africa by mid-summer. WAMME's strategy to place the western lateral boundary at $35^{\circ} \mathrm{W}$ does not yield the optimal MM5 simulation of the summertime northern African climate. In previous studies with the western lateral edge positioned further to the west, MM5 yields a more realistic simulation of the summertime climate (e.g., Vizy and Cook 2002; Hsieh and Cook 2005, 2007; Hagos and Cook 2007; Patricola and Cook 2007).

Figure 5 shows horizontal distributions of precipitation minus evaporation rates (P-E) averaged for June-September 2000, 2003-2005, except that JJAS 2000 is not included in ALMIP (AMMA Land-surface Model Intercomparison Project) data (Boone et al. 2009). ALMIP has produced a multi-model climatology of land surface fluxes over West Africa on a $0.5^{\circ}$ grid, such as evapotranspiration, using forcing derived from a combination of observations, satellite-based data, and numerical model outputs. ALMIP precipitation estimates for Fig. 5 are based on Tropical Rainfall Measurement Mission (TRMM) satellite observations. ALMIP data are used by Xue et al. (2009) to evaluate the simulated surface components of WAMME models. Patterns of modeled P-E without JJAS 2000 (not shown) were almost identical to the four-season means shown in Fig. 5, so the following comparison should not be affected by the noninclusion of JJAS 2000 in the ALMIP data set. In general, local precipitation can be partially supplied by evaporation in situ. In a situation where most precipitation can be traced to local evaporation, P-E is small and there is minimal horizontal moisture convergence. Where precipitation exceeds local evaporation, moisture is presumably imported, so a large seasonal P-E equates with strong horizontal moisture convergence. The implied moisture convergence based on ALMIP data in Fig. 5a explains up to $100 \%$ of observed precipitation rates (Fig. 3a) over the Cameroon Highlands and within parts of the rain band along $10^{\circ} \mathrm{N}$. However, along the windward slopes of the Guinean Highlands, it explains only about $50 \%$ of the observed precipitation, implying a bigger role there for local evaporation. P-E for HadRM3P (Fig. 5b) is generally higher than for ALMIP. For example, overestimates over southwest Mali, implying excessive moisture convergence, indeed correspond to positive rainfall biases of 6-8 $\mathrm{mm}^{-1 a y}{ }^{-1}$ (Fig. 3b). On the other hand, realistic P-E over the Cameroon Highlands yields reasonable precipitation rates, except 
Fig. 5 June-September precipitation minus evaporation: a ALMIP JJAS 2003-2005, b HadRM3P JJAS 2000, 2003-2005, c MM5 JJAS 2000, 2003-2005, d RegCM3 (UC)

JJAS 2000, 2003-2005,

e RegCM3 (UAM) JJAS 2000, 2003-2005

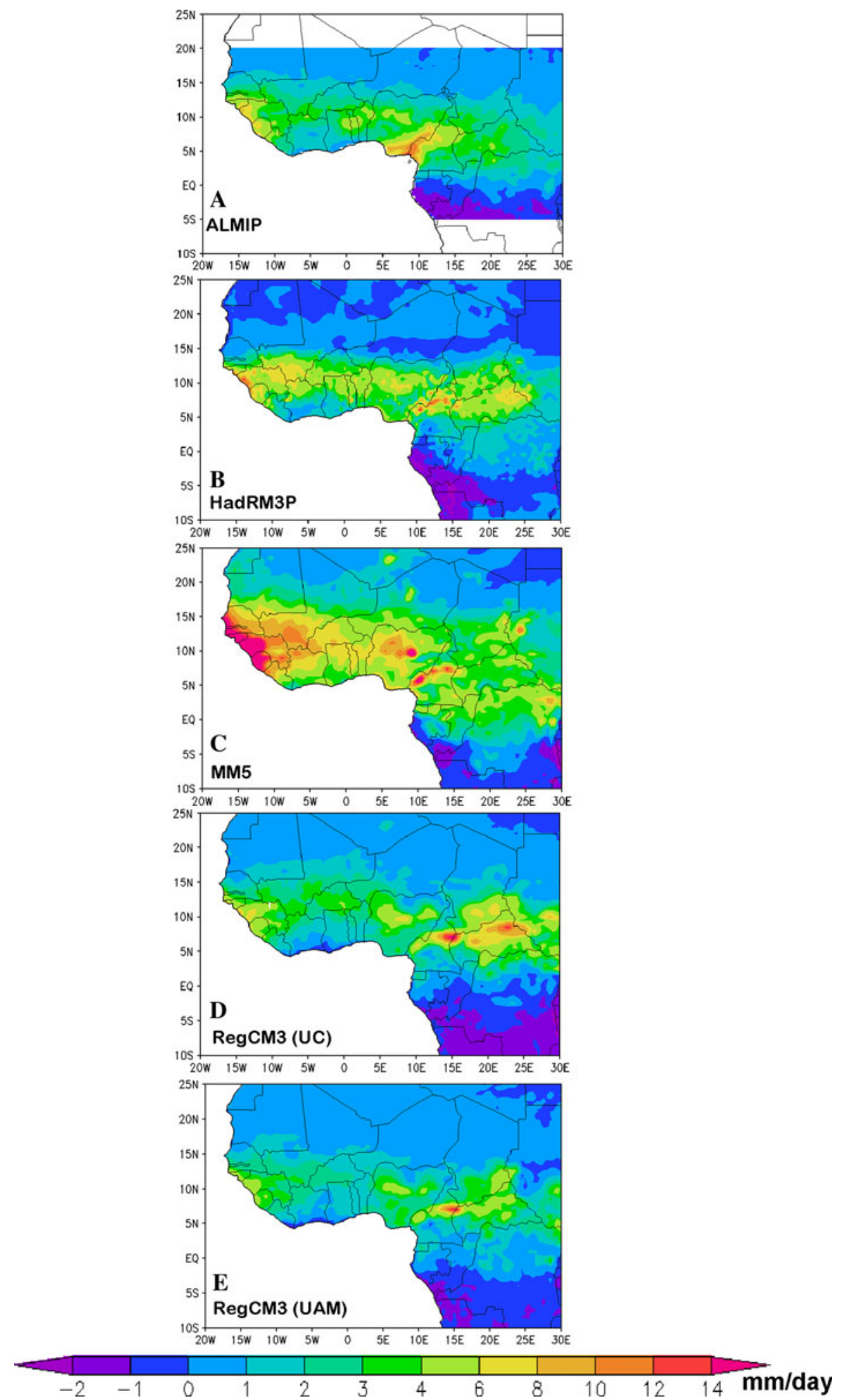

along the immediate coast, where rainfall deficits in Fig. 3b can be traced to weak moisture convergence in Fig. $5 \mathrm{~b}$. Along the Guinean coast, some of the HadRM3P precipitation deficit could derive from inhibitions in triggering moist convection since P-E is not underestimated.
Comparison of Fig. 5c to Fig. 3c shows that excessive MM5 precipitation over much of West Africa corresponds to excessive horizontal moisture convergence, indicated by excessive MM5 P-E. Considered together with Fig. 4d, the analysis shows that excessive moisture advection within the 
monsoon layer results in too much moisture convergence over West Africa, which in turn creates too much rainfall in the MM5 simulations. RegCM3 (UC) P-E (Fig. 5d) resembles the ALMIP distribution, except for underestimates along the Nigeria-Cameroon coast and overestimates over the Central African Republic $\left(8^{\circ} \mathrm{N}, 23^{\circ} \mathrm{E}\right)$. These latter excesses in horizontal moisture convergence correspond to the largest positive RegCM3 precipitation biases evident in Fig. 3d. A second area of excessive rainfall over southwest Niger appears more related to an accelerated hydrological cycle, since P-E there is small. The UAM RegCM3 (Fig. 5e) reproduces a pattern similar to the UC version, but with uniformly lower P-E, consistent with the slightly weaker meridional moisture advection field shown in Fig. 4e. The implied moisture convergence for these simulations is too weak, especially along the Guinea and the Nigerian/Cameroon coasts, leading to large deficits in seasonal precipitation (Fig. 3f). Elsewhere, weaker moisture convergence explains smaller positive precipitation biases of the UAM version. Evapotranspiration rates for RM3 were unavailable.

\subsection{Mean June-September surface air temperature distributions}

Table 2 summarizes the quantitative comparison between modeled June-September 2000, 2003, 2004 and 2005 mean surface air temperature with the corresponding CPC data over the area $5^{\circ} \mathrm{N}-20^{\circ} \mathrm{N}$ and $15^{\circ} \mathrm{W}-20^{\circ} \mathrm{E}$. In the case of temperature, the simulated pattern over this broad area holds more interest than the verification over the subregions monitored for precipitation rates. All data were compared on the models' $0.5^{\circ}$ grid. Table 2 shows the root mean square error (rmse) between each model and the observational data set for all 576 grid elements, the spatial correlation coefficients and the biases of the means in each case. The rmse ranges from 2.36 to $4.10^{\circ} \mathrm{K}$, the correlation coefficients between 0.78 and 0.93 and the biases from -1.79 to $-3.55^{\circ} \mathrm{K}$. In the best case, the HadRM3P

Table 2 Statistical comparison of June-September 2000, 2003-2005 mean surface air temperature for each regional model against CPC GTS observations, gridded at $0.5^{\circ}$ within the area $5^{\circ} \mathrm{N}-20^{\circ} \mathrm{N}, 15^{\circ} \mathrm{W}-$ $20^{\circ} \mathrm{E}$

\begin{tabular}{llll}
\hline Model & $\operatorname{rmse}\left({ }^{\circ} \mathrm{K}\right)$ & $\begin{array}{l}\text { Correlation } \\
\text { coefficient }\end{array}$ & Bias $\left({ }^{\circ} \mathrm{K}\right)$ \\
\hline RM3 & 4.10 & 0.78 & -3.55 \\
HADRM3P & 2.36 & 0.93 & -1.79 \\
MM5 & 2.82 & 0.92 & -2.48 \\
RegCM3 UC & 3.40 & 0.90 & -2.35 \\
RegCM3 UAM & 3.86 & 0.89 & -2.83 \\
\hline
\end{tabular}

Statistics are root mean square error (rmse), correlation coefficient and bias (difference between the means) simulated temperature pattern accounts for $86 \%$ of the spatial variance of observed surface temperature, while it underestimates the observed mean by only $1.79^{\circ} \mathrm{K}$. Negative temperature biases for four of the models are consistent with high evaporation rates and cloudiness implied by their positive precipitation biases (Table 1). In the case of the UAM RegCM3, negative temperature biases occur despite the more realistic simulation of seasonal precipitation rates. The RM3 registered the poorest scores in all three categories and the HadRM3P achieved the best scores.

\subsection{Mean zonal winds}

Figure 6 shows the four-year mean of the June-September mean zonal winds (u) along a north-south transect for which data have been averaged between $10^{\circ} \mathrm{W}$ and $10^{\circ} \mathrm{E}$. The skill with which the RCMs simulate zonal winds over West Africa reflects a wider scope in their performance because (a) the strength of near- surface monsoon westerlies is tightly coupled with the moisture convergence that supplies summer rainfall, (b) the vertical wind shear in the lower troposphere is a direct consequence of the meridional temperature gradient within the lower troposphere between the monsoon air mass and the desert to the north, and (c) the African Easterly Jet (AEJ) interacts with African easterly waves (AEWs) and transports moisture away from the continent.

Figure $6 \mathrm{a}$ and $\mathrm{b}$ show the AEJ at $600 \mathrm{mb}$ near $13^{\circ} \mathrm{N}$ from two observational data sets, each depicting a core speed of approximately $-11 \mathrm{~m} \mathrm{~s}^{-1}$. Near surface monsoon westerlies of less than $5 \mathrm{~m} \mathrm{~s}^{-1}$ are confined to the layer below $800 \mathrm{mb}$, and the Tropical Easterly Jet (TEJ) is manifest by a second u minimum at $200 \mathrm{mb}$ centered over $5^{\circ} \mathrm{N}$. The RM3 and RegCM3 zonal wind cross-sections (Fig. 6c, f) exhibit fairly realistic features, this despite relatively large RM3 errors in surface air temperature (Table 2). The RM3 simulates the AEJ and TEJ cores' strengths and positions quite well although its TEJ extends too far northward. The RM3, HadRM3P (Fig. 6d), and RegCM3 (UC) (Fig. 6f) correctly simulate near surface westerlies near $10^{\circ} \mathrm{N}$ and mid-tropospheric westerlies at $30^{\circ} \mathrm{N}-35^{\circ} \mathrm{N}$. On the other hand, Fig. 6e shows that MM5 features unrealistically strong monsoon westerlies within a monsoon layer that is too deep, and easterlies over the Sahara $\left(30^{\circ} \mathrm{N}\right)$ that are too strong. One consequence is that MM5's mid-tropospheric easterlies representing the AEJ are displaced some $5^{\circ}$ northward and are about $3 \mathrm{~m} \mathrm{~s}^{-1}$ too weak. These deficiencies of MM5 are associated with edge effects along the western lateral boundary of the domain degrading the simulation, as described above. The HadRM3P AEJ occurs at the correct latitude and is slightly too strong, but its vertical wind shear is too weak above 
Fig. 6 Transect of zonal winds for June-September 2000, 2003, 2004 and 2005, averaged between $10^{\circ} \mathrm{W}$ and $10^{\circ} \mathrm{E}$. a, b observational data, c-f regional models
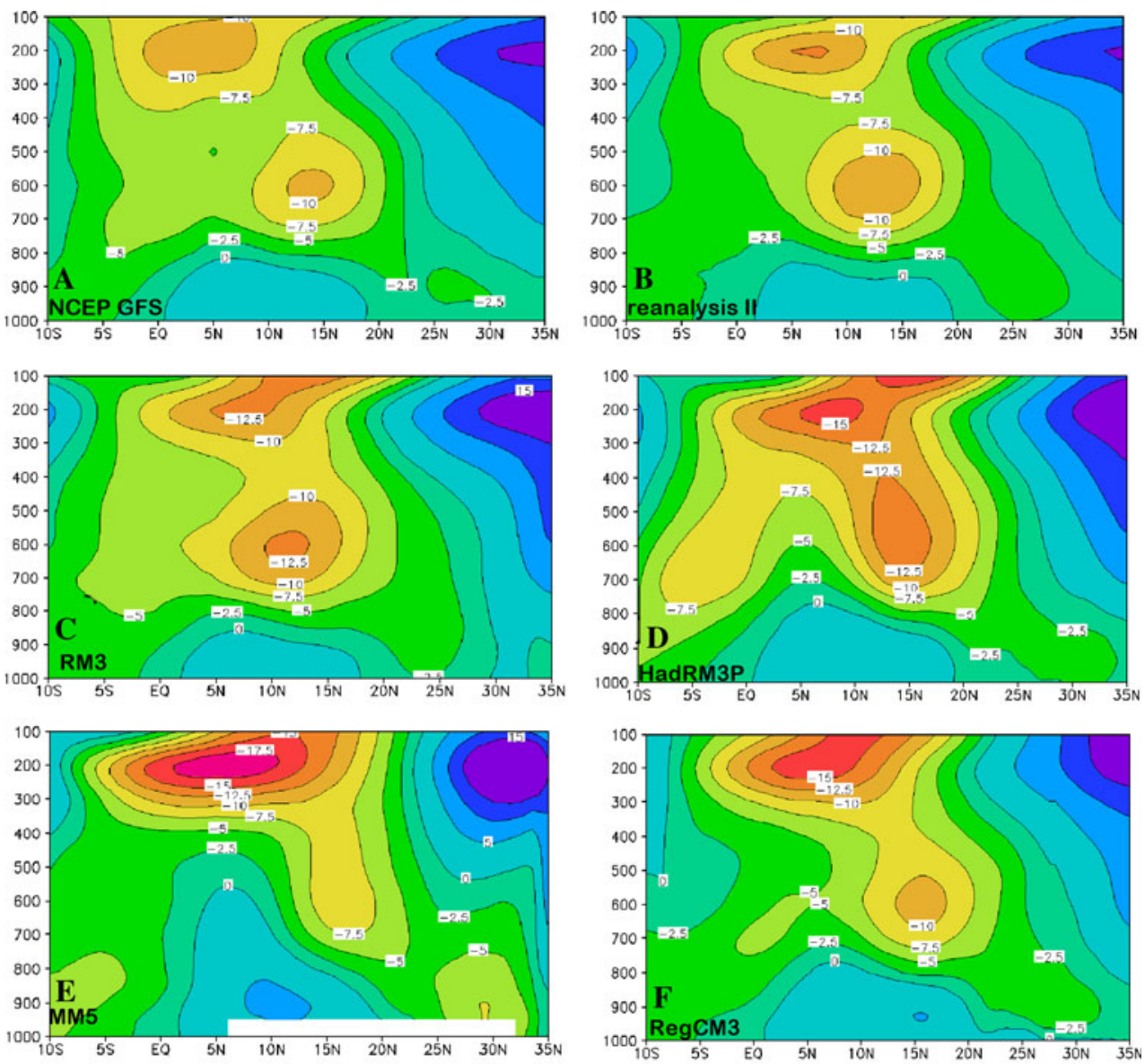

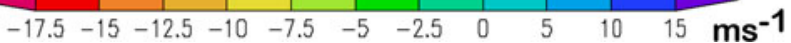

$600 \mathrm{mb}$, vertically stretching the AEJ core. The RegCM3 AEJ is perhaps $2^{\circ}$ too far north, but otherwise quite realistic. HadRM3P, MM5 and RegCM3 simulated TEJ maxima are too strong. Major features of UAM RegCM3 zonal winds (not shown) are much the same as those shown in Fig. $6 f$.

Figure 7 shows the relationship between vertical wind shear $(\Delta \mathrm{u})$ under the AEJ $\left(13^{\circ} \mathrm{N}\right)$ versus the meridional gradient of surface air temperature $(\Delta \mathrm{Ts})$, both averaged between $10^{\circ} \mathrm{W}$ and $10^{\circ} \mathrm{E}$. $\Delta \mathrm{Ts}$ is computed as the difference between Ts at $16^{\circ} \mathrm{N}-20^{\circ} \mathrm{N}$ minus Ts at $6^{\circ} \mathrm{N}-10^{\circ} \mathrm{N}$. JJAS means of these values were computed for each season, 2000, 2003-2005 for two observational data sets and for each model simulation. Figure 7a shows, for GFS data and MM5, HadRM3P and RegCM3 simulations, that larger negative $\Delta \mathrm{u}$ under the AEJ correspond to greater $\Delta \mathrm{Ts}$, although the slope of the relationship for HadRM3P and MM5 seems steeper than for GFS and both RegCM3. The relatively weak $\Delta \mathrm{u}$ of MM5 is explained by its weaker $\Delta \mathrm{Ts}$ in three of the four seasons. The wind shears in the RM3 simulations are quite realistic despite unrealistically small $\Delta \mathrm{Ts}$, while reanalysis II data show little interannual variability in $\Delta$ Ts (Fig. 7 b), perhaps a consequence of the rather coarse $2.5^{\circ}$ grid. Differences between GFS and reanalysis II, both of which are model dependant, reflect an uncertainty in the specification of actual temperature gradients. Wind shear in the RM3 is more consistent with meridional temperature gradients above the surface (not shown). Note that the differences between the models occur despite their sharing common LBC driving data, again emphasizing the consequences of their different parameterizations.

\subsection{Downscaling Hadley Center GCM simulations}

These simulations were conducted with two of the four models described above: RM3 and HadRM3P, driven by LBCs from the HadAM3. Figure 8 shows the June-September 2000, 2003-2005 mean zonal winds averaged between $10^{\circ} \mathrm{W}$ and $10^{\circ} \mathrm{E}$ along a north-south transect for the driving GCM (Fig. 8a) and the two models (Fig. 8b, c). Comparison of Fig. 8a to Fig. 6a and b shows several deficiencies in the GCM's simulation of zonal winds. The near surface monsoon westerlies are too strong and too 

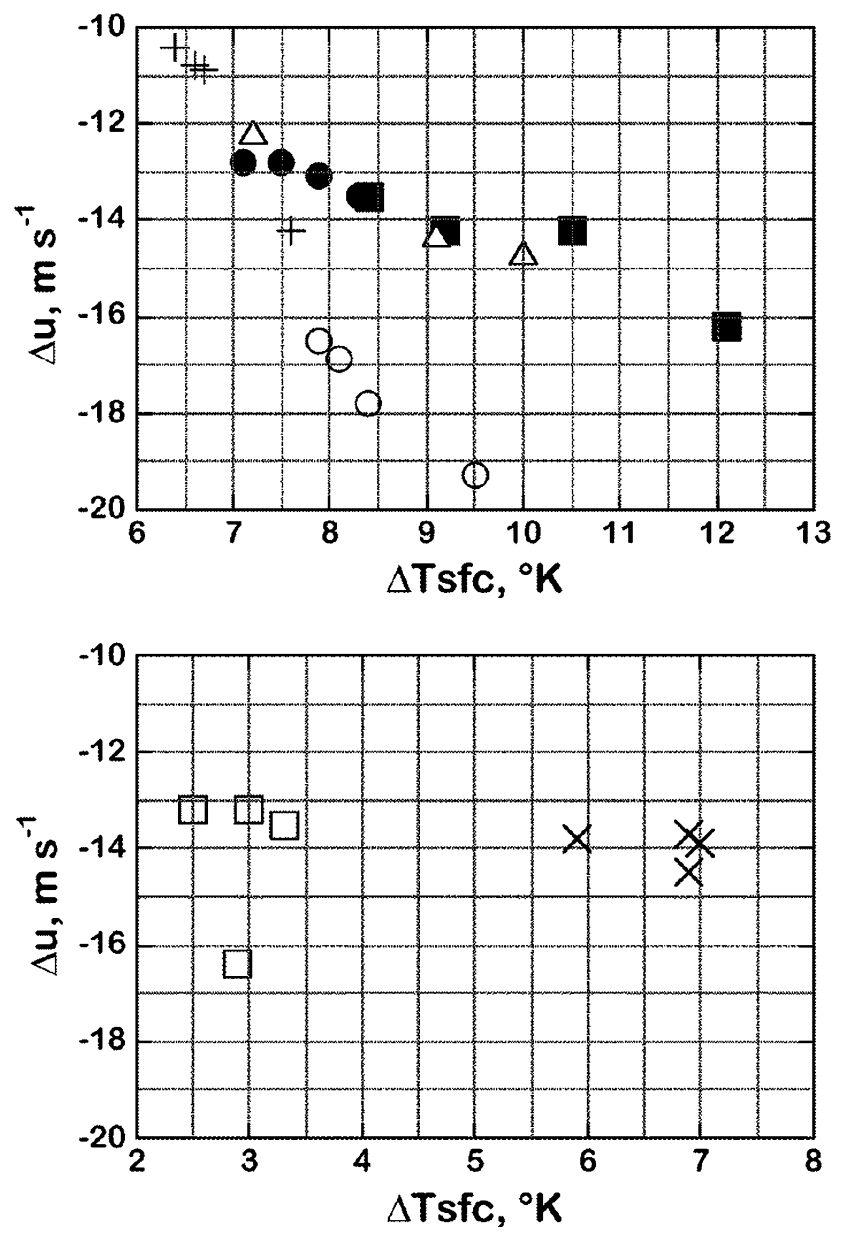

Fig. 7 Zonal wind shear $(\Delta \mathrm{u})$ between 950 and $600 \mathrm{mb}$ over $13^{\circ} \mathrm{N}$ versus the meridional gradient of surface air temperature $(\Delta \mathrm{Ts})$ for the JJAS seasons 2000, 2003, 2004 and 2005. $\Delta \mathrm{u}$ and $\Delta \mathrm{Tsfc}$ are both averaged between $10^{\circ} \mathrm{W}$ and $10^{\circ} \mathrm{E}$ and $\Delta \mathrm{Ts}$ represents the difference between averages at $16^{\circ} \mathrm{N}-20^{\circ} \mathrm{N}$ minus $6^{\circ} \mathrm{N}-10^{\circ} \mathrm{N}$. Open circle HadRM3P, + MM5, filled circle NCP GFS, open triangle UC RegCM3 (2004 missing), filled square UAM RegCM3, open square $\mathrm{RM} 3, \times$ reanalysis

deep, and they penetrate too far northward. The AEJ core is not well defined and the TEJ is too strong. Downscaling with the RM3 (Fig. 8b) improves the latitude and altitude of the simulated AEJ as well as the latitudinal range of the $-5 \mathrm{~m} \mathrm{~s}^{-1}$ isotach, but it does not capture the observed positive vertical wind shear above the AEJ core. It also weakens the near-surface monsoon layer of westerlies too much. Comparison with Fig. 6c shows that the simulation of zonal winds by the RM3 is somewhat less realistic when using HadAM3 LBCs than with NCEP reanalysis II LBCs. Downscaling with the HadRM3P (Fig. 8c) produces no discernable impact on the cross-section of zonal winds. All major features closely resemble the solution of the driving data, despite the increased horizontal and vertical resolutions of the regional model. Comparison of Figs. $8 \mathrm{c}$ and $6 \mathrm{~d}$ also indicates only minor impact of alternative LBCs on this field. The implication is that the physics of HadAM3 and HadRM3P, which is similar between these two models, favors a single solution for the zonal circulation that is relatively insensitive to $\mathrm{LBCs}$ and resolution.

Figure 9 compares the RCMs' May-October 2000, 2003-2005 mean precipitation distribution to observations and to the simulation of the GCM that supplies the LBCs. Regional model precipitation rates were generated on grids of $0.5^{\circ}$ (RM3) and $0.44^{\circ}$ (HadRM3P). CPC observations are gridded at $0.5^{\circ}$, and GCM precipitation was created on the coarser $2.5^{\circ} \times 3.75^{\circ}$ grid. HadRM3P and the HadAM3 GCM are based on similar model physics (although with many different parameter settings), but the differences between the RM3 and GCM results are a consequence of structurally different model physics as well as the different resolutions, and the two influences cannot be separated without additional testing. Inevitably, HadAM3 does not resolve topography as well as the regional models, and this may adversely affect the simulation of orographic rainfall, such as over the Guinea and Cameroon Highlands. Moreover, the coarser HadAM3 resolution may compromise the representation of AEWs, which contain embedded mesoscale precipitation structures.

The orographic precipitation maximum over the Guinea Highlands and along the southwest coast of West Africa, shown in Fig. 9a, extends outward over the adjacent Atlantic Ocean where African wave disturbances (AEWs) intensify. The HadAM3 maximum (Fig. 9b) along the Atlantic coast is too narrow and the second orographic maximum over the Cameroon Highlands is completely missed by HadAM3. RM3 (Fig. 9c) underestimates the Atlantic/Guinea Highlands coastal maximum and slightly exaggerates an otherwise realistic Cameroon maximum. HadRM3P has simulated a very realistic precipitation maximum over the Atlantic coastal region, but it misses most of the inland orographic maximum. Its maximum over the Cameroon Highlands is too narrow and altogether missing from the Cameroon Gulf coast. HadRM3P's underestimation of orographic rainfall in these two regions was previously discussed with reference to Fig. 3c, which shows the results of downscaling the reanalysis. This implies a model deficiency rather than the negative influence of unrealistic boundary data. The RM3, however, gave very small precipitation biases over the Guinea Highlands (Fig. 3b) when forced by reanalysis, suggesting that the GCM LBC diminish RM3 precipitation production at the Atlantic coast.

Both RCMs improve on HadAM3 precipitation rates within the West African zonal rainfall maximum, which is about 30\% too high in HadAM3. In fact, both the RM3 and HadRM3P, forced by HadAM3, show lower positive precipitation bias than the parallel simulations forced by reanalysis. 
Fig. 8 Transect of zonal winds for June-September 2000, 2003, 2004 and 2005, averaged between $10^{\circ} \mathrm{W}$ and $10^{\circ} \mathrm{E}$. a HadAM3 GCM, b RM3, c HadRM3P. RCMs driven by HadAM3 LBC
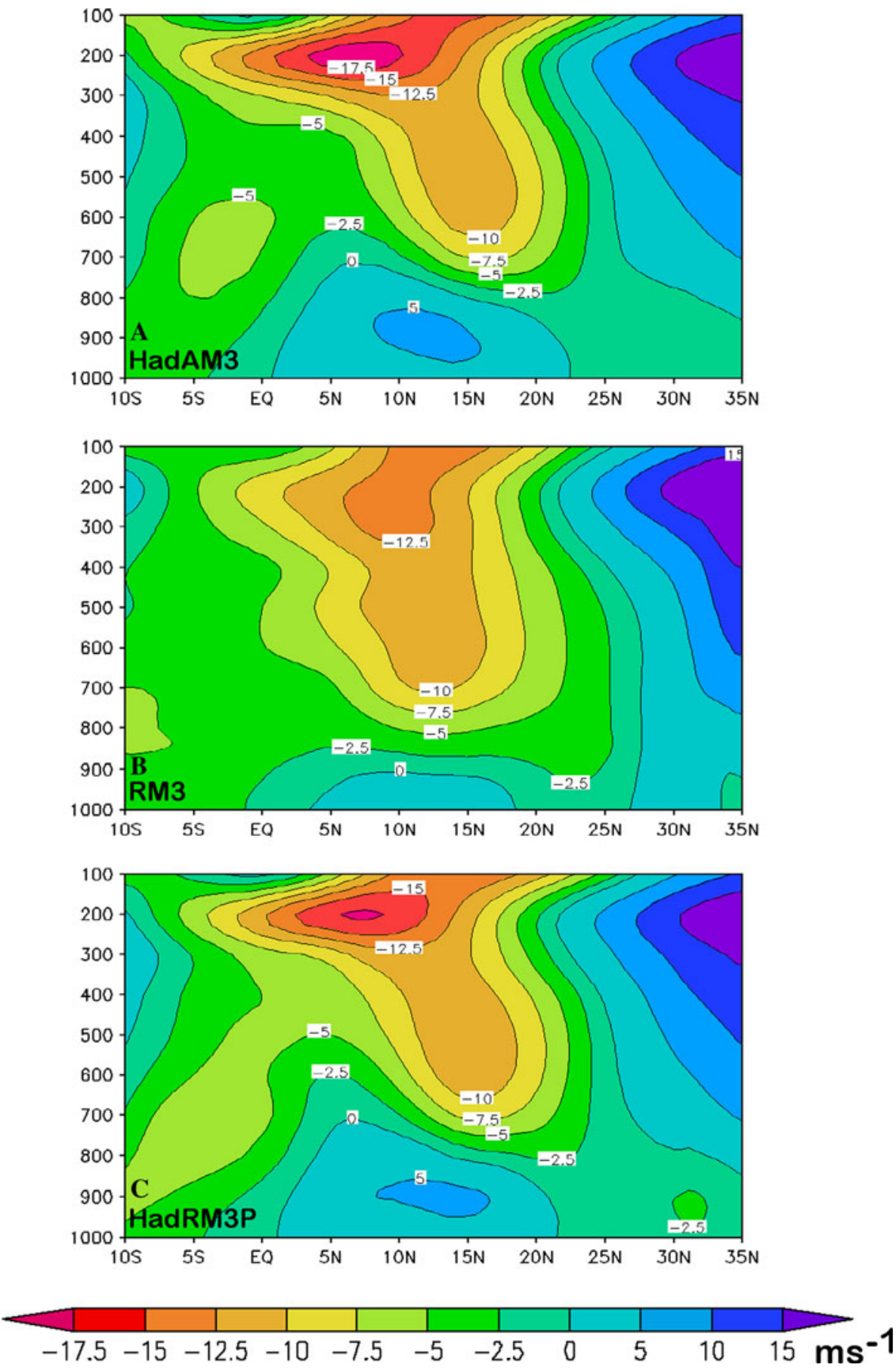

Observations confirm a rather steep rainfall gradient between the rain belt and the Sahara (Fig. 9a), with the $2 \mathrm{~mm}$ day $^{-1}$ isohyet running along $14^{\circ} \mathrm{N}-15^{\circ} \mathrm{N}$. HadAM3 cannot resolve this gradient (Fig. 9b) and it simulates a more diffuse boundary, with its $2 \mathrm{~mm} \mathrm{day}^{-1}$ isohyet reaching as far north as $19^{\circ} \mathrm{N}$. Both regional models achieve sharper gradients (Fig. 9c, d). The RM3 places the gradient along the correct latitudes, while the HadRM3P rain band encroaches northward too far. The HadRM3P precipitation distribution (Fig. 9d) shows high spatial variability, but there is no evidence that any of this detail is real.

Figure 10 shows the June-September 2000, 2003-2005 $950 \mathrm{mb}$ circulation and 950-mb meridional moisture advection for NCEP reanalysis II, for HadAM3 and for the two RCM simulations driven by HadAM3 LBCs. HadAM3 computes stronger southwesterlies over West Africa than NCEP reanalysis II and its northward moisture advection penetrates much further inland. However, HadAM3 northward moisture advection is reduced over the Gulf of Guinea 


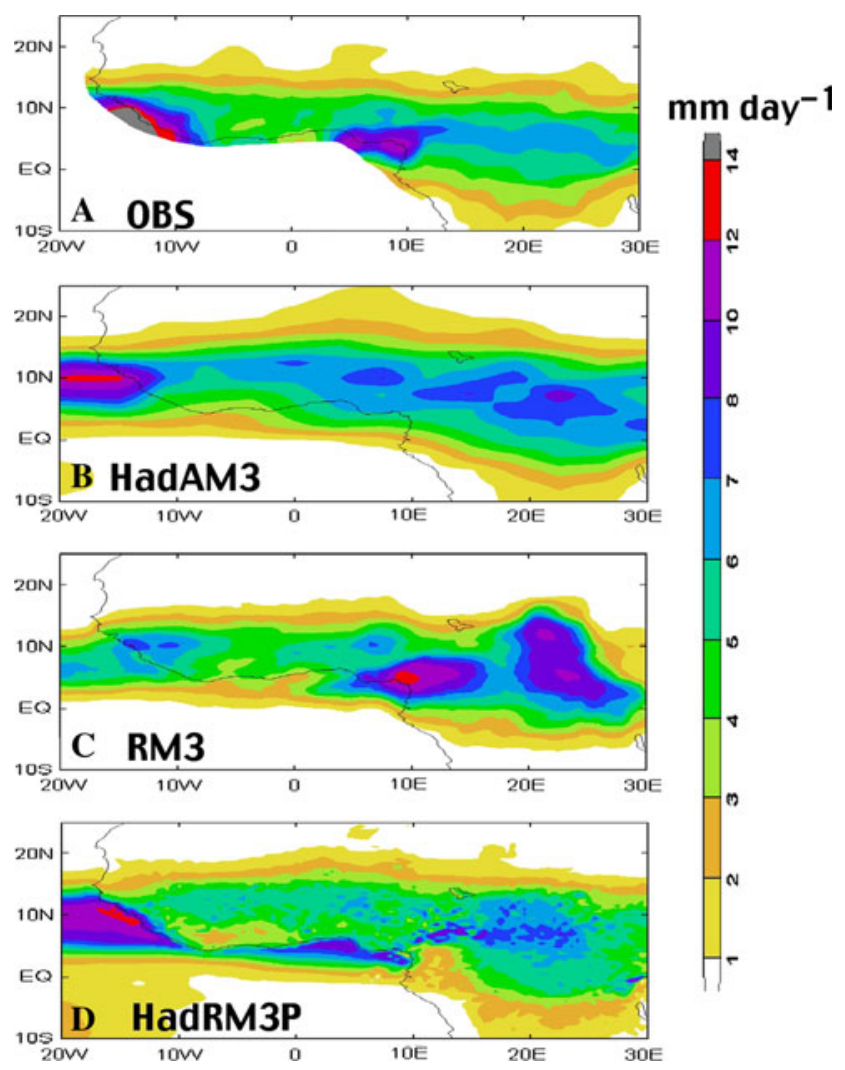

Fig. 9 May-October 2000, 2003-2005 mean precipitation rates $\left(\mathrm{mm}\right.$ day $\left.^{-1}\right)$ a CPC GTS observations, b HadAM3, c RM3, d HadRM3P. RCMs driven by HadAM3 LBC

compared to reanalysis. HadRM3P makes only minor adjustments to the driving simulation, increasing northward moisture advection near $17^{\circ} \mathrm{N}$ while decreasing it in the lee of the Guinean Highlands near $10^{\circ} \mathrm{N}, 10^{\circ} \mathrm{W}$. Many of the features shown in Fig. 10c are similar to the HadRM3P $950 \mathrm{mb}$ moisture advection and circulation forced by reanalysis (Fig. 4c), suggesting that model physics and resolution (especially of topography) exert a stronger influence on lower tropospheric moisture advection and circulation than LBC. On the other hand, RM3 results demonstrate a greater sensitivity to LBC. Figure $10 \mathrm{~d}$ shows weaker circulation and weaker northward moisture advection than Fig. $4 \mathrm{~b}$, weaker even than in the HadAM3 driving data (Fig. 10b). Figure 9c shows that the RM3 positive precipitation bias was lower with HadAM3 LBCs over three of the four sub-regions than for the simulation driven by NCEP reanalysis II LBC. The more realistic precipitation rates may derive from the combination of unrealistically weak meridional moisture advection and overactive moist convection.

\subsection{Interannual precipitation differences}

The most basic challenge for the modeling system in seasonal climate prediction is to correctly forecast spatial

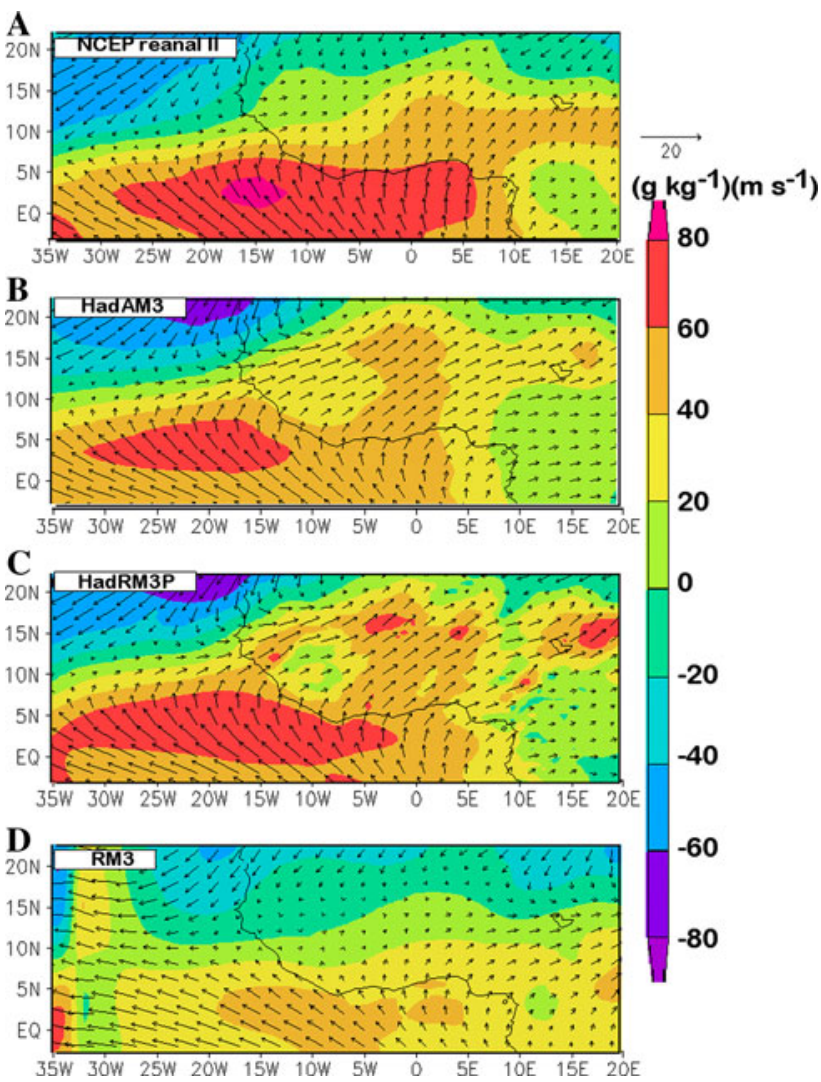

Fig. $10950 \mathrm{mb}$ circulation and meridional moisture advection. a NCEP reanalysis II, b HadAM3, c HadRM3P, d RM3. RCMs driven by HadAM3 LBC

patterns of climate anomalies. Since anomalies are departures from climatological means, and this study analyzes only a 4-year sample of simulations, an alternative representation of interannual variability is examined here. Of the four seasons considered in this study, the JJAS 2000 season was the driest over the Sahel, in contrast to rainier conditions during JJAS 2003 and 2005, based on the CPC rain gauge data. Figure 11a shows the spatial distributions of JJAS mean observed precipitation differences, JJAS 2003 minus 2000 and 2005 minus 2000, hereafter $\triangle \mathrm{Pcp} 03$ and $\triangle \mathrm{Pcp} 05$, respectively, from the CPC data. Both distributions show positive differences of up to about $5 \mathrm{~mm}$ day ${ }^{-1}$ along the southwest coast of West Africa, with positive differences of $1-4 \mathrm{~mm}$ day $^{-1}$ over the rest of the Guinea Highlands and within the $12^{\circ} \mathrm{N}$ rain band.

Can the RCMs capture this interannual signal in precipitation when forced by "perfectly" forecast SST anomalies? Do the RCMs improve on the prediction of the GCM driving them? Results here are from single realizations for each season, and must be interpreted with caution since they do not account for the models' internal variability. This question is more acute for the GCM than for the RCMs. Experiments by Druyan et al. (2007) and Vanvyve et al. (2008) show that a given set of LBCs 
drive a given regional model toward a unique seasonal mean precipitation pattern over West Africa, with negligible sensitivity to initial conditions. On the other hand, the LBCs used to drive the RCMs in the current experiments are taken from a single GCM simulation for each season, and therefore do not include the range of variability that ensembles would provide. Figure $11 \mathrm{~b}$ shows the HadAM3 GCM predictions of the two difference fields, forced by HadlSST1 lower boundary conditions. While the GCM correctly indicates a narrow swath of positive $\Delta \mathrm{Pcp} 05$ precipitation differences along $12^{\circ} \mathrm{N}$, the $\triangle \mathrm{Pcp} 03$ result is approximately the inverse of the observed pattern. These discrepancies could arise from chaotic internal atmospheric variations that cannot be captured in the single GCM simulations used here, especially since the GCM has no LBC forcing. Indeed, HadAM3's interannual anomalies are found to be closer to observed when ensemble means are analyzed (ameliorating the impact of internal variability) and statistics are improved with a large sample of years (Rowell et al. 1992; Rowell 2001, 2003). Both the RM3 (Fig. 11c) and HadRM3P (Fig. 11d) improve the GCM prediction for $\triangle \mathrm{Pcp} 05$ but RM3 fares no better than the GCM in generating the $\triangle \mathrm{Pcp} 03$ differences. The HadRM3P simulation of the $\triangle \mathrm{Pcp} 03$ is a marginal improvement over the GCM. Interestingly, the HadRM3P simulations forced by NCEP reanalysis II (Fig. 11f) were not decisively better forecasts of the observed interannual precipitation differences. However, the RM3 simulation forced by the reanalysis (Fig. 11e) did improve on the $\Delta \mathrm{Pcp} 03$ field from the downscaled forecast in that it reproduced the observed swath of positive differences along $12^{\circ} \mathrm{N}$. Perhaps in this case, the more realistic atmospheric boundary conditions of the reanalysis provide some of the necessary forcing to produce the observed $\Delta \mathrm{Pcp} 03$ differences over West Africa.

Figure 12a shows a diagnostic field based on NCEP reanalysis II data that provides some explanation of the positive $\Delta$ Pcp05 differences. JJAS 2005 minus JJAS 2000 lower tropospheric vector wind differences are southerly along the entire southwest and southern coast of West Africa. Thus, stronger southerlies in JJAS 2005 produce greater northward transports of water vapor flux that, in turn, enhance JJAS 2005 precipitation rates relative to JJAS 2000. This is quite relevant even though it does not consider possible JJAS 2005 minus 2000 differences in moisture divergence by the AEJ (Rowell et al. 1992; Cook 1999). None of the models reproduces the differential lower tropospheric circulation or moisture advection field (Fig. 12b-f), implying that modeled positive $\triangle \mathrm{Pcp} 05$ differences, where they occur, may not be simulated by the same mechanism identified in the NCEP reanalysis II.

\section{Conclusions}

This study explores the potential for downscaling seasonal climate prediction over West Africa, focusing on standardized RCM simulations of the West African summer monsoon climate as part of the WAMME initiative. An intercomparison is made of the results from four RCMs, each driven by synchronous NCEP reanalysis II and C20C SST data over four May-October seasons. The second part of the study analyzes results from two of the RCMs, driven with GCM (HadAM3) forcing and the same SST lower boundary conditions.

All four RCMs simulate the northward jump of the precipitation band that represents monsoon onset over Sahelian Africa. The jumps in three of the four models were $2-5$ weeks earlier than observed, suggesting serious model limitations for predicting monsoon onset. All of the RCMs show positive precipitation biases over much of West Africa, consistent with positive precipitation biases within the West African rain belt in NCEP reanalysis II and HadAM3 (Xue et al., 2009), the two data sets used for LBC. One RCM generated spurious precipitation for the entire season over parts of the Sahara desert, an apparent consequence of adverse lateral boundary effects. The fivemodel average precipitation bias for June-September mean rates over West Africa $\left(5^{\circ} \mathrm{N}-20^{\circ} \mathrm{N}, 15^{\circ} \mathrm{W}-20^{\circ} \mathrm{E}\right)$ was about $1.7 \mathrm{~mm} \mathrm{day}^{-1}$ and the average spatial correlation between modeled and observed mean rainfall rates over the same area was 0.82 , which means that the simulated pattern accounts for $67 \%$ of the observed spatial variance. Much of that success comes from correctly locating orographic precipitation maxima, the latitude of the main west to east rain band and the transition to the desert regime to the north. RCM performance in simulating the seasonal mean precipitation distribution compared to observations was generally better north of $10^{\circ} \mathrm{N}$. Spatial correlation coefficients against the observed pattern are near 0.90 for all RCMs within the Sahel belt centered on $15^{\circ} \mathrm{N}$, but are in the range of $0.30-0.65$ for more southerly sub-regions. The four- model average surface air temperature bias for JuneSeptember means over West Africa $\left(5^{\circ} \mathrm{N}-20^{\circ} \mathrm{N}, 15^{\circ} \mathrm{W}-\right.$ $20^{\circ} \mathrm{E}$ ) is $-2.6^{\circ} \mathrm{K}$ and the average spatial correlation between modeled and observed mean surface air temperature is 0.88 . UAM RegCM3 results incurred the lowest bias and rmse for seasonal mean precipitation and HadRM3P for surface air temperature. While benefits of HadRM3P higher horizontal resolution are as yet undocumented, some favorable simulation features could be a consequence of choices in model physical parameterizations, shared by HadRM3P and HadAM3.

HadRM3P and RegCM3 simulate local minima and maxima in lower tropospheric meridional moisture advection that can be identified with West African topographic 
Fig. 11 JJAS 2005 minus 2000 (left column) and JJAS 2003 minus 2000 (right column) precipitation rate differences $\left(\mathrm{mm} \mathrm{day}^{-1}\right)$. a CPC GTS observations, b HadAM3 GCM, c RM3 w/HadAM3 LBC, d HadRM3P w/HadAM3 LBC, e RM3 w/NCEP reanalysis II LBC, f HadRM3P w/NCEP reanalysis II LBC
A

JJAS 2005 minus 2000

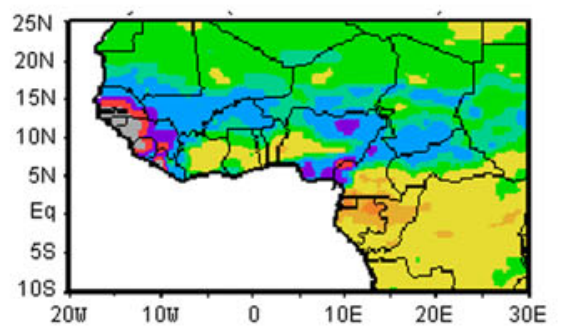

JJAS 2003 minus 2000
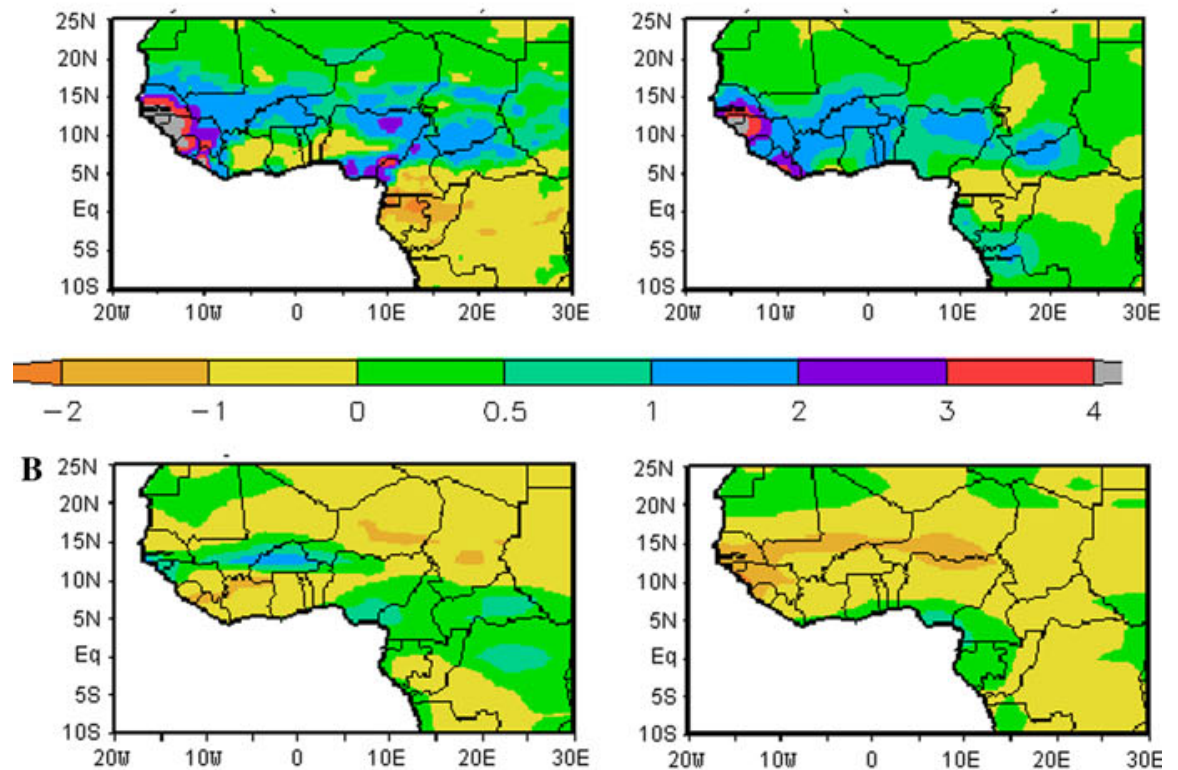

C 2

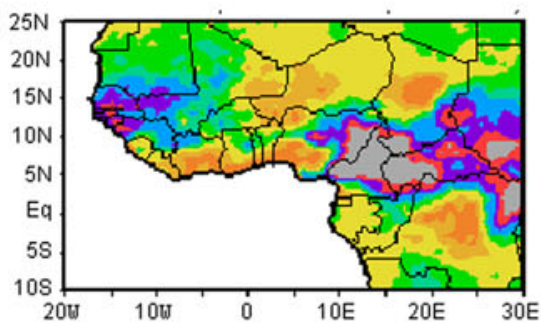

D

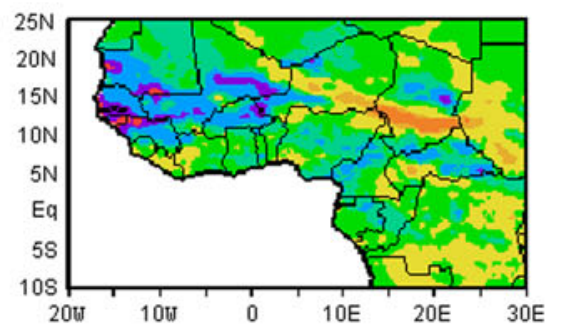

E 25
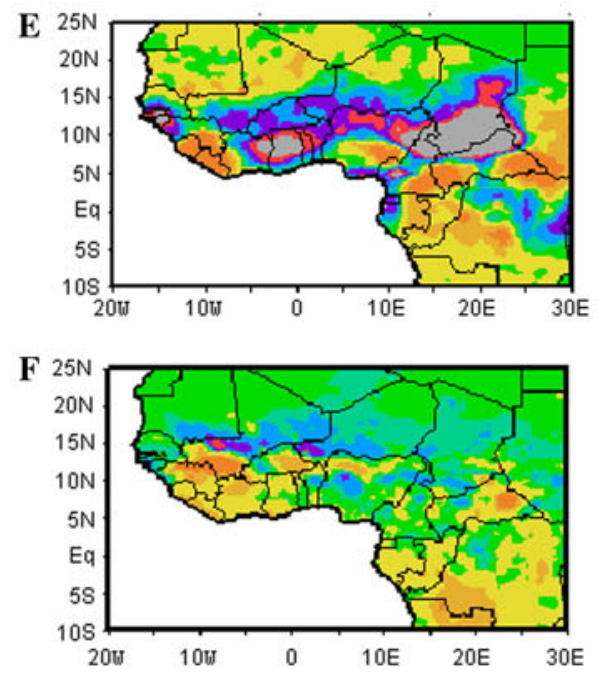
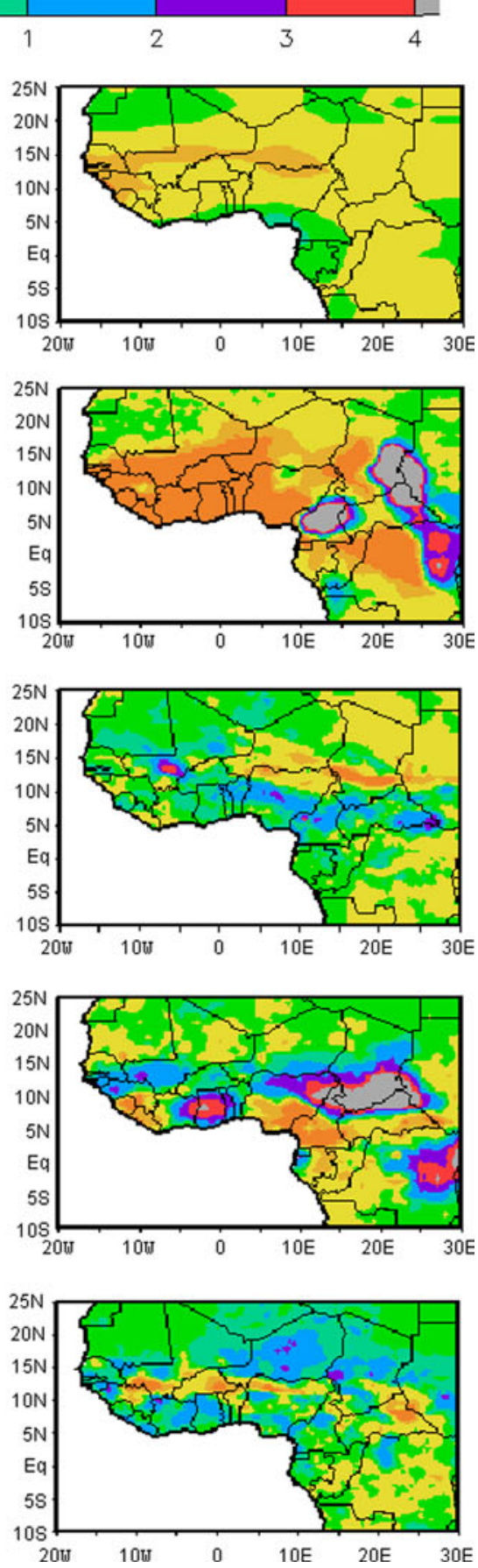
Fig. 12 JJAS 2005 minus JJAS 2000 differences in $950 \mathrm{mb}$ vector winds (arrows) and in $950 \mathrm{mb}$ meridional moisture advection (color bar) $\left(\mathrm{g} \mathrm{kg}^{-1}\right)$ $\left(\mathrm{m} \mathrm{s}^{-1}\right)$, for a NCEP reanalysis II, b RM3/reanalysis II LBC, c HadRM3P/NCEP reanalysis II LBC, d HadAM3, e RM3/ HadAM3 LBC, f HadRM3P/ HadAM3 LBC
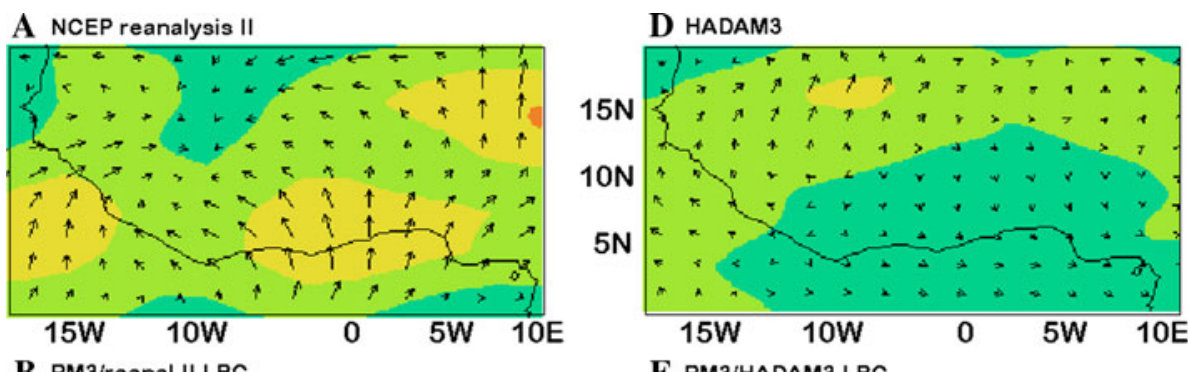

B RM3ireanal II LBC
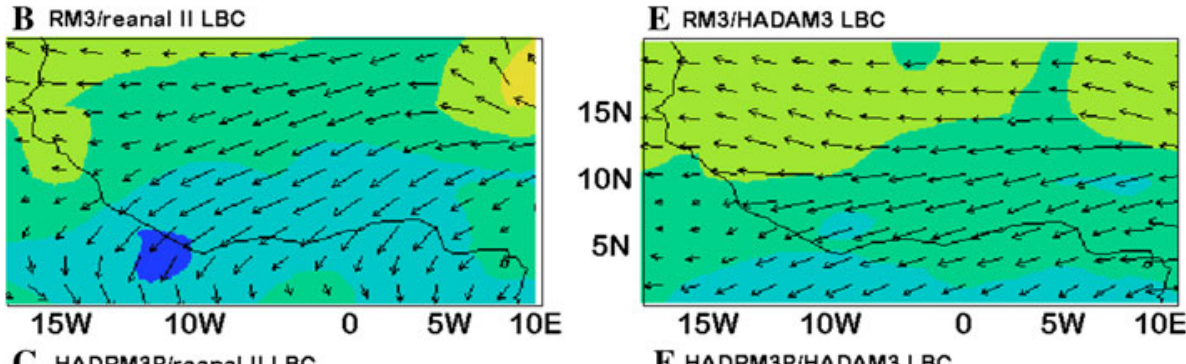

C HADRM3Pireanal II LBC
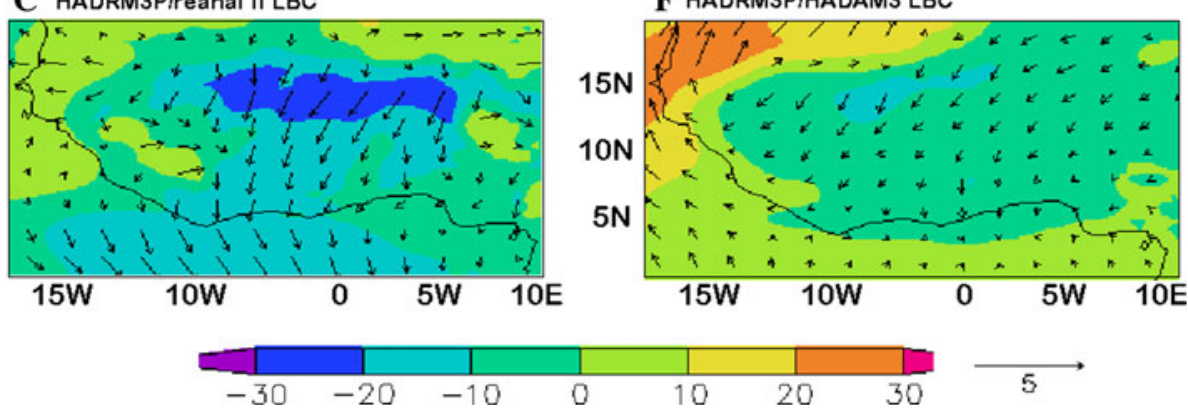

features, which are better resolved by the RCMs than by either NCEP reanalysis II or the HadAM3 GCM. MM5 suffers excessive moisture advection in the monsoon layer, leading to overestimates of moisture convergence over West Africa and large precipitation biases. Excessive moisture convergence also explains some of the more modest HadRM3P precipitation excesses. RegCM3 JJAS estimates of moisture convergence over West Africa are mostly consistent with observations, although the RegCM3 forced by OISST develops larger positive precipitation biases than the RegCM3 forced by HadlSST1. The latter eliminates much of the bias by weakening moisture convergence over West Africa.

The GCM simulation and several of the RCM simulations did not show a distinct seasonal mean AEJ core in the zonal wind cross section. The MM5 gave a poor representation of many features of the zonal circulation over the region, including the AEJ, near surface layer of monsoon westerlies and the TEJ. This same model exhibited excessive meridional moisture advection and positive precipitation biases over most of West Africa and the Sahara Desert. The AEJ core is a geostrophic consequence of strong meridional surface temperature gradients supported by the pronounced surface moisture gradients across the Sahel (Cook 1999). The variation in surface conditions is communicated to the atmosphere when latent heating in the south is replaced by dry convection farther north (Thorncroft and Blackburn 1999). An ill-defined AEJ can therefore be symptomatic of flaws in the juxtaposition of simulated dry and moist convection over West Africa, or in the simulation of surface temperature and moisture fields. Interannual differences in seasonal mean zonal wind shear under the AEJ for four of the five RCMs reflect the corresponding differences in meridional gradient of the seasonal mean surface air temperature.

The difficulties MM5 had in realistically simulating the summertime climate are largely a product of the experimental design choices by WAMME to constrain all of the RCM models to common lateral boundaries. Compelling the western boundary to be located at $35^{\circ} \mathrm{W}$ resulted in the development of an edge effect in the MM5 simulation over the northern Atlantic Ocean in the vicinity of the ITCZ. Over time, this unrealistic response propagated into the model domain and degraded the model results over West Africa. Other studies using the MM5 RCM (e.g., Vizy and Cook 2002; Hsieh and Cook 2005, 2007; Hagos and Cook 2007; Patricola and Cook 2007) have shown that if the western boundary is extended westward, or if the domain is enlarged, the edge effect disappears from the simulations and a realistic summer climate simulation is achieved. Future RCM comparison projects need to consider allowing greater flexibility to individual RCMs to set the lateral 
edges in a way that can optimize the model results for a focus region of interest, but still constrain the simulations to a common standard as close as possible. Differences in the results between the RCMs, despite their sharing the same driving $\mathrm{LBCs}$, emphasize the importance of model physics in determining the quality of simulations.

GCM flaws in the mean zonal circulation were slightly improved by downscaling with the RM3, one of two RCMs, although that model produced a more realistic cross section of the main zonal wind features with NCEP reanalysis II forcing. The errors in HadRM3P's simulation of the zonal wind profiles were found to be robust, irrespective of the LBCs, and also close to those of the similar HadAM3 GCM. One can deduce that simulation of the easterly jets in the Hadley Centre models is rather insensitive to horizontal and vertical resolution, and simulation deficiencies are probably related to flaws in the physical parameterizations they share. Nevertheless, HadRM3P and HadAM3 GCM produce distinctly different precipitation fields.

Several spatial features of the GCM seasonal mean precipitation distribution appear to be improved by downscaling, but each RCM also fails to improve on other features. Multi-year seasonal mean precipitation fields are less biased when generated by GCM forcing than by reanalysis forcing. Although it is possible that the GCM LBCs provide some benefits that improve on reanalysis II LBCs, it is perhaps more likely that regional model deficiencies neutralize GCM data deficiencies to produce a more favorable outcome. For example, RM3 zonal wind structure and meridional moisture advection are less realistic with GCM LBCs than with reanalysis II LBCs, even while generating smaller precipitation errors. HadRM3P meridional moisture advection in the lower troposphere is similar for both sets of LBCs.

Systematic model biases can be neutralized by considering interannual differences. Nevertheless, the GCM JJAS 2005 minus 2000 differences in precipitation rates exhibit only some of the observed signal of positive differences over the Sahel, perhaps due to chaotic internal atmospheric fluctuations that cannot be reliably modeled by single realizations. Dynamic downscaling of the GCM results by two of the RCMs appears to noticeably improve the GCM simulation of the relative precipitation anomalies. However, none of the models simulates the observed JJAS 2005 relative excess in northward moisture advection, implying that positive $\Delta$ pr05 is not consistently simulated by the mechanism identified in the observational analysis. Observed $\triangle \mathrm{Pcp} 03$ differences are not captured by the GCM or the RCMs, except when reanalysis II is downscaled by the RM3. Overall, the study does not provide strong evidence that single RCM integrations can make skillful seasonal predictions of regional precipitation anomalies, neither by downscaling HadAM3 forecasts, nor by downscaling potentially more skillful forecasts, represented here by NCEP reanalysis II. Further assessments using ensemble data are required.

In the next phase of WAMME, a different design for the RCM intercomparison will be considered. In designing the first phase, the placement of the lateral boundaries and the horizontal resolution for the RCM simulations were specified based on previous investigations using the RM3 model. But RCMs are always sensitive to the placement of these boundaries (Xue et al. 2007), and moving them farther away from the region of interest can help to improve simulations and minimize adverse boundary effects. A great strength of the RCM approach is to produce a realistic modeled climate through judicious choice of model parameterizations and lateral boundary placement and conditions. As for global models, better results will also require improvements in model physics. Perhaps a better strategy for a model intercomparison study will be to leave the positioning of the boundaries free for selection-similar to the physical parameterizations - and select a common analysis region. Additional testing comparing downscaling results using different sources of data for LBCs, SST and initial soil moisture and temperature will help clarify the relative sensitivity of results to model parameterizations versus initial and driving data. Positive bias in simulated precipitation rates by the RCMs can perhaps be reduced by optimization based on a much longer simulation history than was produced for these WAMME experiments. In addition, a better evaluation of the 'added value' that RCMs can provide at interannual timescales should be made through the use of ensembles of multi-year simulations. These issues will be addressed during the continuation of WAMME.

Acknowledgments LD and MF were supported by NSF award ATM-0652518, NASA grant NNX07A193G and the NASA Climate and Earth Observing System Program. YX and JF were supported by NSF award ATM-0751030. MM5 research was supported by NSF award ATM-0415481 and U.S. DOE CCPP award ER64610. Acknowledgment for computing time is made to the Third World Academy of Sciences (TWAS) and the National Center for Atmospheric Research, which is sponsored by the National Science Foundation. DPR and WM-O were funded by the Joint DECC, Defra and MoD Integrated Climate Programme, GA01101, CBC/2B/ 0417_Annex C5. We gratefully acknowledge the helpful suggestions of two anonymous reviewers.

Open Access This article is distributed under the terms of the Creative Commons Attribution Noncommercial License which permits any noncommercial use, distribution, and reproduction in any medium, provided the original author(s) and source are credited.

\section{References}

Afiesimama E, Pal J, Abiodun B, Gutowski W, Adedoyin A (2006) Simulation of West African monsoon using the RegCM3. Part I: model validation and interannual variability. Theor Appl Climatol 86:23-37. doi:10.1007/s00704-005-0202-8 
Boone A, de Rosnay P, Basalmo G, Beljaars A, Chopin F, Decharme B, Delire C, Ducharne A, Gascoin S, Guichard F, Gusev Y, Harris P, Jarlan L, Kergoat L, Mougin E, Nasonova O, Norgaard A, Orgeval T, Ottlé C, Poccard-Leclercq I, Polcher J, Sandholt I, Saux-Picart S, Taylor C, and Xue Y (2009) The AMMA Land Surface Model Intercomparison Project (ALMIP). Bull Am Meteor Soc (in press)

Cook KH (1999) Generation of the African easterly jet and its role in determining West African precipitation. J Clim 12:1165-1184

De Ela R, Laprise R, Denis B (2002) Forecasting skill limits of nested, limited-area models: a perfect-model approach. Mon Weather Rev 130:2006-2023

Denis B, Laprise R, Caya D, Coté J (2002) Downscaling ability of one-way nested regional climate models: the Big-Brother Experiment. Clim Dyn 18:627-646

Druyan L, Fulakeza M, Lonergan P (2007) Spatial variability of regional model simulated June-September mean precipitation over West Africa. Geophys Res Lett 34:L18709. doi:10.1029/ 2007GL031270

Druyan L, Fulakeza M, Lonergan P (2008) The impact of vertical resolution on regional model simulation of the West African summer monsoon. Int J Climatol 28:1293-1314. doi:10.1002/ joc. 1636

Folland CK, Palmer T, Parker D (1986) Sahel rainfall and worldwide sea temperatures, 1901-85. Nature 320:602-607

Giannini A, Saravanan R, Chang P (2003) Oceanic forcing of Sahel rainfall on interannual to interdecadal time scales. Science 302:1027-1030. doi:10.1126/science. 1089357

Grell GA, Dudhia J and Stauffer DR (1994) A description of the fifthgeneration Penn State/NCAR mesoscale model (MM5). NCAR Technical Note, NCAR/TN-398 + STR, p 121

Hagos SM, Cook KH (2007) Dynamics of the West African monsoon jump. J Clim 20:5264-5284

Hsieh J-S, Cook KH (2005) Generation of African easterly wave disturbances: relationship to the African easterly jet. Mon Weather Rev 133:1311-1327

Hsieh J-S, Cook KH (2007) A study of the energetics of African easterly waves. J Atmos Sci 64:421-440

Huffman GJ, Adler RF, Arkin P, Chang A, Ferraro R, Gruber A, Janowiak J, McNab A, Rudolph B, Schneider U (1997) The Global Precipitation Climatology Project (GPCP) combined precipitation data set. Bull Am Meteorol Soc 78:5-20

Jones R, Noguer M, Hassell D, Hudson D, Wilson S, Jenkins G, Mitchell J (2004) Generating high resolution climate change scenarios using PRECIS. Met Office Hadley Centre, Exeter, p 40

Kanamitsu M, Ebisuzaki W, Woollen J, Yang SK, Hnilo JJ, Fiorino M, Potter GL (2002) NCEP-DOE AMIP-II reanalysis (R-2). Bull Am Meteorol Soc 83:1631-1643

Messager C, Gallée H, Brasseur O (2004) Precipitation sensitivity to regional SST in a regional climate simulation during the West African monsoon for two dry years. Clim Dyn 22:249-266

Moufouma-Okia W and Rowell DP (2009) Impact of soil moisture initialization and lateral boundary conditions on regional climate simulations of the West African Monsoon Climate Dynamics. Clim Dyn (in press)

Paeth H, Born K, Podzun R, Jacob D (2005) Regional dynamical downscaling over West Africa: model evaporationaluation and comparison of wet and dry years. Meteorlogische Zeitschrift 14:349-367

Pal J, Giorgi F, Bi X, Elguindi N, Solmon F, Gao X, Rauscher S, Francisco R, Zakey A, Winter J, Ashfaq M, Syed F, Bell J, Diffenbaugh N, Karmacharya J, Konare A, Martinez D, Da Rocha R, Sloan L, Steiner A (2007) Regional climate modeling for the developing world: the ICTP RegCM3 and RegCNET. Bull Am Meteorol Soc 88:1395-1409

Patricola CM, Cook KH (2007) Dynamics of the West African monsoon under mid-Holocene precessional forcing: regional climate model simulations. J Clim 20:694-716

Pope VD, Gallani ML, Rowntree PR, Stratton RA (2000) The impact of new physical parametrizations in the Hadley Centre climate model: HadAM3. Clim Dyn 16:123-146. doi:10.1007/s0038200 50009

Ramel R, Gallée H, Messager C (2006) On the northward shift of the West African monsoon. Clim Dyn 26:429-440. doi:10.1007/ s00382-005-0093-5

Rayner NA, Parker DE, Horton EB, Folland CK, Alexander LV, Rowell DP, Kent EC, Kaplan A (2003) Global analyses of SST, sea ice and night marine air temperature since the late nineteenth century. J Geophys Res 108: (D14)

Reynolds RW, Rayner NA, Smith TM, Stokes DC, Wang W (2002) An improved in situ and satellite SST analysis for climate. J Clim 15:1609-1625

Rojas M, Seth A (2003) Simulation and sensitivity in a nested modeling system for tropical South America. Part II: GCM boundary forcing. J Clim 16:2454-2471

Rowell DP (2001) Teleconnections between the Tropical Pacific and the Sahel. Q J R Meteorol Soc 127:1683-1706

Rowell DP (2003) The impact of Mediterranean SSTs on the Sahelian rainfall season. J Clim 16:849-862

Rowell DP, Folland CK, Maskell K, Owen JA, Ward MN (1992) Modelling the influence of global sea surface temperatures on the variability and predictability of seasonal Sahel rainfall. Geophys Res Lett 19:905-908

Sultan B, Janicot S (2000) Abrupt shift of the ICTZ over West Africa and intra-seasonal variability. Geophys Res Lett 27:3353-3356

Sylla, M, Gaye A, Pal J, Jenkins G, Bi X (2009) High-resolution simulations of West African climate using regional climate model (RegCM3) with different lateral boundary conditions. Theor Appl Climatol, online first. doi:10.1007/s00704-009-0110-4

Thorncroft C, Blackburn M (1999) Maintenance of the African easterly jet. Q J R Meteorol Soc 125:763-786

Vanvyve E, Hall N, Messager C, Leroux S, van Ypersele J (2008) Internal variability in a regional climate model over West Africa. Clim Dyn 30:191-202

Vizy EK, Cook KH (2002) Development and application of a mesoscale climate model for the tropics: influence of sea surface temperature anomalies on the West African monsoon, JGR 107(D3). doi:10.1029/2001JD000686

Xie P, Yatagai A, Chen M, Hayasaka T, Fukushima Y, Liu C, Yang S (2007) A gauge-based analysis of daily precipitation over East Asia. J Hydrometeorol 8:607-626

Xue Y, Vasic R, Janjic Z, Mesinger F, Mitchell KE (2007) Assessment of dynamic downscaling of the continental U.S. regional climate using the Eta/SSiB Regional Climate Model. J Clim 20:4172-4193

Xue Y, De Sales F, Lau K-M, Boone A, Feng J, Dirmeyer P, Guo Z, Kim K-M, Kitoh A, Kumar V, Poccard-Leclercq I, Mahowald N, Moufouma-Okia W, Pegion P, Schubert S, Sealy A, Thiaw W, Vintzileos A, Wu M-L (2009) Intercomparison of West African Monsoon and its variability in the West African Monsoon Modeling and Evaluation Project (WAMME) First GCM Experiment. Clim Dyn (submitted)

Taylor KE, Williamson D, Zwiers, F, (2000) The sea surface temperature and sea-ice concentration boundary conditions for AMIP II simulations. PCMDI Report No. 60, Lawrence Livermore National Laboratory, Livermore, CA, p 25 